Estudios Constitucionales, Año 15, No 2, 2017, pp. 229-272

ISSN 07180105

Centro de Estudios Constitucionales de Chile Universidad de Talca

"Análisis comparativo de los mecanismos de protección de derechos humanos en la comisión legislativa dentro del ordenamiento jurídico de México y Colombia"

Alfonso Jaime Martínez Lazcano - Jaime Cubides Cárdenas - María Camila Moreno Torres

\title{
ANÁLISIS COMPARATIVO DE LOS MECANISMOS DE PROTECCIÓN DE DERECHOS HUMANOS EN LA OMISIÓN LEGISLATIVA DENTRO DEL ORDENAMIENTO JURÍDICO DE MÉXICO Y COLOMBIA*
}

ANALYSIS OF MECHANISMS FOR THE PROTECTION OF HUMAN RIGHTS IN THE LEGISLATIVE OMISSION WITHIN THE LEGAL SYSTEM OF MÉXICO AND COLOMBIA

\author{
Alfonso Jaime Martínez Lazcano* \\ Universidad Autónoma de Chiapas \\ alfonso.martinez@unach.mx \\ Jaime Cubides Cárdenas ${ }^{* * *}$ \\ Universidad Católica de Colombia, \\ jacubides@ucatolica.edu.co \\ Marfa Camila Moreno Torres ${ }^{* * *}$ \\ Universidad Católica de Colombia \\ mcmoreno24@ucatolica.edu.co
}

\footnotetext{
* Trabajo recibido el 15 de julio de 2017 y aprobado el 4 de octubre de 2017.

** Investigador Nacional del Sistema Nacional de Investigadores Conacyt Nivel I, Doctor en Derecho Público, profesor e investigador de la Universidad Autónoma de Chiapas y profesor honorario de la Facultad de Derecho de la Universidad Nacional Autónoma de México. Director de la Revista Jurídica Primera Instancia. Contacto: alfonso.martinez@unach.mx.

*** Abogado y especialista en Derecho Público de la Universidad Autónoma de Colombia, especialista y Magíster en Docencia e Investigación con énfasis en las ciencias jurídicas de la Universidad Sergio Arboleda y Magíster en Derecho de la misma casa de estudios, estudiante de Doctorado en Derecho en la línea de investigación de Derecho Constitucional de la Universidad de Buenos Aires-Argentina. Docente Investigador y Líder del grupo de investigación Persona, Instituciones y Exigencias de Justicia de la Universidad Católica de Colombia. Contacto: jacubides@ucatolica.edu.co.

**** Investigadora auxiliar, vinculada al grupo de investigación "Persona, Instituciones y exigencias de Justicia del Centro de Investigaciones Sociojurídicas (CISJUC)" de la Facultad de Derecho de la Universidad Católica de Colombia. Estudiante de la misma casa de estudios. Contacto: momoreno24@ucatolica.edu.co.

Artículo de investigación que expone resultados de investigación el proyecto titulado "Desafíos contemporáneos para la protección de Derechos Humanos en escenarios de posconflicto desde enfoques interdisciplinarios", que forma parte de la línea de investigación Fundamentación e implementación de los Derechos Humanos, del grupo de investigación Persona, Instituciones y Exigencias de Justicia, reconocido y categorizado como Tipo A por COLCIENCIAS y registrado con el código COL0120899, vinculado al Centro de Investigaciones Socio jurídicas (CISJUC), adscrito y financiado por la Facultad de Derecho de la Universidad Católica de Colombia.
} 
RESUMEN: En el presente texto se desarrolla el análisis investigativo acerca de los mecanismos de protección de los Derechos Humanos, cuando se encuentren vulnerados por una omisión legislativa; su propósito es demostrar la viabilidad de dichos mecanismos mediante los órganos constitucionales competentes. Esta necesidad obliga a que se expanda la protección dentro de cada ordenamiento jurídico, es por esto que se manejará el tema en los paises de México y Colombia; asi mismo, se propone que se unifique como único mecanismo de control dentro de todo el territorio mexicano el juicio de amparo, para combatir la inactividad legislativa, y asi garantizar los derechos humanos.

De igual forma, en Colombia la vulneración de derechos humanos que genera el vacio normativo se puede mediar a través de la acción de inconstitucionalidad. Lo anterior se ejemplificará con varias sentencias dentro de cada ordenamiento jurídico interno y se esclarecerán los requisitos de procedibilidad de cada mecanismo de protección. Asimismo, se evidenciará una comparación de los procesos constitucionales de los citados Estados.

PALABRAS CLAVE: Omisión legislativa, derechos humanos, juicio de amparo, acción de inconstitucionalidad.

ABSTRACT: This paper develops an analytical framework to study the enforcement of Human Rights in cases of Legislative omission. The purpose of the study is to demonstrate the legal viability of enforcing rights though the means afforded by the constitutional judiciary. The need for enforcement mechanisms absent legislative action obliges to an expansion of protection of rights through judicial activism. The object of study will be the laws of Colombia and Mexico as case studies. In Mexico, the special injunction of "amparo" is proposed as a mechanism that can cover the whole country in the event of legislative silence and protect human rights. In Colombia, the action of inconstitutionality is a mechanism to invoke legal protection in case of legislative omission. This study will showcase the relevant case law of Colombia and México the events where the national legislator omits to protect Human Rights and the procedural requirements needed in both jurisdictions to coaxed judicial intervention.

KEYWORDS: Legislative omission, human rights, writ of amparo, unconstitutionality action.

\section{INTRODUCCIÓN}

El Poder Legislativo en su facultad reglamentaria, cuando deja de emitir una ley, reglamento o realizar reforma a las mismas, para que desarrolle mandatos constitucionales, constituye un comportamiento denominado omisión legislativa. Lo anterior se puede dar por negligencia, descuido, desinterés o por la lucha política interna en los órganos parlamentarios; este vacío se torna en forma concreta como un "no hacer" por parte del legislador, sin embargo, no es suficiente que exista el deber legal de legislar, para que se funde dicha omisión, sino que el "no hacer" debe comprometer preceptos constitucionales y el legislador incumplir con la obligación constitucional.

Así mismo, dicha pasividad respecto al desarrollo legislativo compromete derechos humanos, vulnerando su exigibilidad y cumplimiento en específico, al grado de producir una afectación, daño o perjuicio; por lo cual resulta razonable crear los mecanismos constitucionales o medios de control que se puedan utili- 
zar; además de constituir los órganos competentes para expandir la protección y regular el abandono reglamentario por parte del legislador, mediante el juicio de amparo y la acción de inconstitucionalidad.

Con el propósito de realizar un análisis general antes de llevar a cabo cada situación en particular de los países de Colombia y México, en el presente título se realizarán las aclaraciones conceptuales principales en relación con la omisión legislativa, en donde cada concepto se expondrá de manera general, en base al desarrollo de ambas naciones y continuación en cada país.

\section{NOCIONES GENERALES DE LA OMISIÓN LEGISLATIVA}

La omisión se puede entender como la falta del que ha dejado de hacer algo conveniente, obligatorio o necesario en relación con alguna cosa, y respecto de la omisión de deberes, es aquel incumplimiento de los compromisos activos impuestos a las autoridades por el rol democrático que están obligados a desempeñar, se origina por la abstención y la responsabilidad de las mismas cuando han de actuar de oficio, y también si desatienden los justificados requerimientos de los particulares o actúan sin celo o con malicioso retraso. ${ }^{1}$

En México, cabe aclarar que la orden de legislar puede ser explícita, como en el caso de las llamadas reserva de ley, donde el constituyente encarga al legislador la confección de preceptos que ejecuten y pongan en movimiento el contenido de la Carta Fundamental. ${ }^{2}$ Hecha esta salvedad, del concepto de la omisión legislativa, se pueden analizar los siguientes elementos: ${ }^{3}$

A. Se trata, en primer lugar, de no reducir la omisión legislativa inconstitucional a un simple no hacer, a una mera abstención u omisión, sino de identificar una exigencia constitucional de acción.

B. En segundo lugar, que las omisiones legislativas inconstitucionales derivan del incumplimiento de mandatos que vinculan al legislador a la adopción de medidas legislativas de concreción constitucional, que producen un daño o perjuicio.

C. También existe omisión cuando, aun existiendo la norma legislativa, en realidad ésta tiene tales carencias que la convierten en inútil en relación con el mandato constitucional que pretenden desarrollar y dotar de garantías adecuadas

1 Cabanellas (1963), p. 15.

2 Zapata (2014), p. 16.

3 GÓMEZ (1993), p. 1089. 
para su protección, esto es, por un insuficiente desarrollo que la haga impráctica y produzca perjuicios a una persona determinada.

En relación con lo anterior, el legislador genera un vacío en el contenido normativo, produciendo efectos a una persona o un grupo determinado; dejando sin efectividad y cumplimiento las exigencias de los derechos humanos y fundamentales. Dicho en otras palabras, el legislador con el silencio altera el contenido normativo de la Constitución Política, por lo cual ostenta la calidad de inconstitucional. ${ }^{4}$ Se infiere que los derechos fundamentales pueden resultar violados por el legislador desde dos perspectivas: mediante la expedición de leyes que vulneren precisamente esos derechos limitándolos o restringiéndolos; o con la omisión de establecer normas que dispongan de la satisfacción de esos derechos. 5

Por otra parte, en Colombia se entiende que existe una omisión legislativa, cuando el legislador no cumple un deber de acción expresamente señalado por el Constituyente. Es por esto que la Corte Constitucional ha establecido los elementos donde el legislador puede constituir una omisión legislativa: cuando no produce ningún precepto encaminado a ejecutar el deber concreto que le ha impuesto la Constitución; cuando, en cumplimiento del deber impuesto por la Constitución, favorece a ciertos grupos, perjudicando a otros; cuando, en desarrollo de ese mismo deber, el legislador en forma expresa o tácita excluye a un grupo de ciudadanos de los beneficios que otorga al resto; cuando el legislador, al regular o construir una institución, omite una condición o un ingrediente que, de acuerdo con la Constitución, sería exigencia esencial para armonizar con ella. ${ }^{6}$

El deber de legislar es impuesto al legislador por preceptos constitucionales de obligatorio desarrollo, son normas imperativas ${ }^{7}$ que requieren de un desarrollo ulterior, de obligación del órgano legislativo, que consiste en la expedición de una ley que desarrolle el respectivo precepto constitucional. En este sentido, es la misma Constitución que le impone al órgano legislativo la obligación de legislar, porque es una competencia indubitable del legislador, quien no tiene la opción de elegir si expide o no una norma concreta. ${ }^{8}$ En consonancia con lo anterior, la

\footnotetext{
4 Villaverde (1997), p. 35.

5 Ferrajoli (2001), p. 66.

6 Corte Constitucional, sentencia C-041/2002, 30 de enero de 2002.

7 Son aquellas normas jurídicas que posee un contenido del que los sujetos jurídicos no pueden prescindir, de manera que la regulación normativa que se haga de la materia tendrá completa validez independientemente de la voluntad del individuo.

8 GonZÁles (2014), p. 6.
} 
omisión se da por voluntad del legislador, porque no puede hacer caso omiso a un mandato constitucional que lo obliga a expedir la ley, es decir, no queda en tela de juicio la decisión.

La Corte Constitucional ha sostenido que las normas constitucionales no deben correr el riesgo de quedarse escritas, porque ello llevaría indefectiblemente a la pérdida de su valor normativo y de los fines inspiradores del ordenamiento constitucional. Los fines esenciales del Estado 9 imponen al órgano legislativo el deber de llevar a cabo, en un plazo razonable ${ }^{10}$, las reformas y desarrollos legales necesarios para garantizar la efectividad de las decisiones del constituyente. ${ }^{11}$ Factores que aún no se encuentran regulados en la normatividad ni se ha impuesto el tiempo, como se mencionaba anteriormente, para que el legislador cumpla sus obligaciones.

Sin embargo, para la existencia de la omisión legislativa, no siempre requiere del transcurso de un tiempo "excesivamente largo". Este elemento temporal es irrelevante cuando nos hallamos ante una omisión relativa del legislador fundada en la violación al principio de igualdad. ${ }^{12}$

\section{Supremacia constitucional}

La supremacía constitucional es un principio básico y elemental del contenido de los medios de control constitucional. Este principio consiste en la cualidad de fungir como la norma jurídica superior que da validez y unidad a un orden jurídico nacional. ${ }^{13}$ Es por esto que toda norma, para que sea válida, tiene que garantizar la supremacía constitucional.

Por lo que se refiere que todo proceso o procedimiento de esta naturaleza, tendrá en su contenido el determinar el acatamiento del acto u omisión impugnado, a lo ordenado por la Constitución Política: es decir, una litis de carácter constitucional.

\footnotetext{
9 La finalidad misma del Estado es fortalecer la unidad de la Nación y asegurar a sus integrantes la vida, la convivencia, el trabajo, la justicia, la igualdad, el conocimiento, la libertad y la paz. (CuBIDES, Grandas y GonZÁLEZ, 2015, p. 46).

10 De forma general, los convenios, acuerdos y tratados internacionales, en materia de derechos humanos, han plasmado en sus textos la protección y garantía que tiene cualquier persona que sea acusada de cometer hechos punibles a que se le juzgue dentro de un plazo razonable, de donde se desprende que existen diferentes clases de plazo razonable (Cubides, CAstro y BARRETo, 2017, p. 14).

11 Corte Constitucional, Sentencia C-188/1996. 8 de mayo de 1996.

12 Cubides, et al. (2015), p. 7.

13 BAEZ (2002), p. 382.
} 
Así, la Constitución es la fuente última de validez de un ordenamiento jurídico, de tal suerte que, para una norma jurídica, cualquiera que sea válida, deberá ser conforme con la Constitución. ${ }^{14}$

En México cabe señalar que el artículo 133 de la Constitución Política de los Estados Unidos Mexicanos (en lo sucesivo, CPEUM) establece que "las leyes del Congreso de la Unión que emanen de ella y todos los Tratados que estén de acuerdo con la misma, celebrados y que se celebren por el presidente de la República, con aprobación del Senado, serán la Ley Suprema de toda la Unión. Los jueces de cada Estado se arreglarán a dicha Constitución, leyes y tratados, a pesar de las disposiciones en contrario que pueda haber en las Constituciones o leyes de los Estados". Esto dispone que en toda actuación se debe resguardar la supremacía constitucional, por encima de las demás normas ordinarias de la legislación. De esta manera, más que una facultad, la supremacía constitucional impone a toda autoridad el deber de ajustar a los preceptos fundamentales, los actos desplegados en ejercicio de sus atribuciones. ${ }^{15}$

Por otro lado, para que puedan operar las controversias constitucionales, en sentido amplio, es necesario establecer la hegemonía de las normas constitucionales sobre cualquier otro acto, además, por cuestión esencial de orden, primero es ineludible crear las normas y principios fundamentales a las que deban ceñirse las demás disposiciones.

Como bien dice Luz Bulnes, el principio de supremacía constitucional, sustento del constitucionalismo contemporáneo, supone necesariamente el control de las infracciones a la Constitución, las cuales pueden originarse tanto en acciones positivas que violenten la Ley Fundamental, como en omisiones que contraríen los preceptos que ella consagra. ${ }^{16}$ Sin este orden cualquier sistema jurídico estaría condenado al fracaso.

Igualmente, la Constitución es el documento político principal en cuyo contenido se encuentran normas fundamentales del sistema jurídico, las cuales están en la cúspide del universo del derecho mexicano, a ésta deben sujetarse todos los actos de los gobernantes, quienes están obligados al cumplimiento cabal de sus postulados. Es necesario establecer una jerarquía formal no material, una serie de

14 Diccionario juridico mexicano (2002), p. 3023.

15 Semanario Judicial de la Federación (1999), p. 18.

16 BulNes (2006), p. 253. 
categorías, donde unas sucedan a las otras, para evitar, en lo posible, el incumplimiento a las de mayor rango, y los mecanismos de corrección cuando esto ocurra.

En este orden de ideas, la Constitución es ley primaria de un Estado soberano, en ésta se establecen los límites y obligaciones de las autoridades; se definen las relaciones entre los gobernados y gobernantes, así como la estructura y competencias de quienes detentan el poder, fijando así en la Constitución las bases para gobernar.

Es por esto que la norma de normas para su eficacia requiere de instrumentos de defensa, para hacer efectiva su preminencia frente a cualquier ley secundaria, acto u omisión, que limite o restrinja sus postulados y directrices. Cabe señalar que todo acto u omisión de autoridad, incluyendo los del legislador, que sean contrarios a la Constitución deben ser combatidos, para corregirse y abolirse. Este análisis se ve reflejado en el contenido del derecho sustantivo constitucional. Los preceptos: $1^{\circ}$, 40 y 133 de la CPEUM establecen la jerarquía del orden jurídico nacional.

Así, Arteaga Nava dice: "En la Constitución mexicana es el principio que establece su supremacía, el que determina su jerarquía superior respecto de todo el orden normativo que existe en el país, el que le da tributo de ser fundamental y que asigna a todo lo que no sea ésta el carácter de derivado, el que le atribuye su calidad de superior se ha consignado con fines netamente pragmáticos... El principio se consigna de manera general de dos formas: una explícita, en el art. 40 , el que dispone que es una ley fundamental... la otra, implícita, que se desprende del término que se utiliza para denominarla: constitución; lo es porque constituye, faculta y limita". ${ }^{17}$ De acuerdo con lo anterior, la Constitución no debe convertirse en un documento lleno de buenas intenciones y estériles disposiciones. De ahí que es vital la defensa de su acatamiento mediante una serie de instrumentos de control de los actos de las autoridades.

La supremacía de las normas se consagra mediante los siguientes presupuestos: ${ }^{18}$

A. Su creación corresponde a un órgano superior a los órganos instituidos en mismas normas fundamentales.

B. Para su modificación se sigue un procedimiento distinto, mucho más complicado, que para cambiar las normas que derivan de ellas.

C. Establecen los mecanismos de creación del resto de las normas jurídicas.

D. Ninguna norma derivada puede ser contraria ni formal (procedimiento) ni materialmente (contenido) a estas normas fundamentales.

17 Arteaga (2003), p. 13.

18 BAEZ (2002), p. 393. 
Hecha esta salvedad, partiendo del principio inexcusable, en los Estados de derecho, de la supremacía de la Constitución, se han de reputar como inconstitucionales todos los actos, leyes, decretos o resoluciones que se aparten de sus normas o las contradigan ${ }^{19}$. Consideremos brevemente que dentro del Estado mexicano siempre se habían creado mecanismos de protección a las conductas positivas (de hacer) y no se contemplaba la posibilidad de que una conducta pasiva del legislador (no hacer) vulnerara la Constitución Política. ${ }^{20}$

Por otra parte, en Colombia la noción de supremacía constitucional parte de la naturaleza normativa de la Constitución, que se revela en el carácter de fuente primaria del ordenamiento jurídico. En tal sentido, el artículo 4 de la Constitución Política indica: "La Constitución es norma de normas. En todo caso de incompatibilidad entre la Constitución y la ley u otra norma jurídica, se aplicarán las disposiciones constitucionales". Así, la naturaleza normativa del orden constitucional es la clave de la sujeción del orden jurídico restante a sus disposiciones, en virtud del carácter vinculante que tienen sus reglas. Tal condición normativa y prevalente de las normas constitucionales, la sitúan en el orden jurídico como fuente primera del sistema de derecho interno, comenzando por la validez misma de las normas infraconstitucionales, cuyas formas y procedimientos de producción se hallan regulados en la propia Constitución. De ahí que la Corte haya expresado: "La Constitución se erige en el marco supremo y último para determinar tanto la pertenencia al orden jurídico como la validez de cualquier norma, regla o decisión que formulen o profieran los órganos por ella instaurados. El conjunto de los actos de los órganos constituidos -Congreso, Ejecutivo y jueces- se identifica con referencia a la Constitución y no se reconoce como derecho si desconoce sus criterios de validez. La Constitución como lex superior precisa y regula las formas y métodos de producción de las normas que integran el ordenamiento y es por ello 'fuente de fuentes', norma noramum. Estas características de supremacía y de máxima regla de reconocimiento del orden jurídico propias de la Constitución, se expresan inequívocamente en el texto del artículo 4". ${ }^{21}$

En consecuencia, el concepto de supremacía normativa de la Carta Política es definitorio del Estado Social y constitucional de Derecho, debido a la fuerza normativa de la Constitución, las autoridades no sólo están sometidas al derecho

19 Osorio (1992), p. 211.

20 Rangel (2008), p. 205.

21 Corte Constitucional, Sentencia C-415 de 2012, 6 de junio de 2012. 
positivo de la norma superior, sino también para la realización efectiva de los derechos subjetivos consagrados constitucionalmente. ${ }^{22}$

\section{Clasificación de las normas constitucionales}

En el presente tema es importante destacar que las normas constitucionales tienen diferentes características según su tipo y que, en cada país, la clasificación de las mismas puede variar.

En México, la Constitución cuenta con diversas clases de normas, algunas de eficacia propia y otras requieren para su vigencia una ley reglamentaria, así como las que prevén aspectos político-sociales.

Carlos Báez Silva, apoyándose en Gustavo Sagrebelsky, explica claramente los tipos de normas constitucionales ${ }^{23}$ :

a) Normas de eficacia directa: las que son "idóneas de por sí (directamente) para regular situaciones concretas".

b) Normas de eficacia indirecta: las que "necesitan ser actuadas o concretadas a través de una posterior actividad normativa".

Estas son normas no suficientemente completas como para poder ser operadas o aplicadas en forma directa por los oficiales de la administración pública, los particulares o los jueces. Requieren para ello un posterior desarrollo normativo, atendiendo al sistema de fuentes que la propia Constitución establezca. En esta categoría se ubican diferentes tipos de normas:

Normas constitucionales de eficacia diferida: son disposiciones de organización de los llamados "poderes" estatales y de sus instancias de dirección. Por ejemplo, no obstante, las reglas específicas de los artículos 51 a 54 de la CPEUM, es necesario contar con una ley electoral que los desarrolle para integrar las cámaras federales; por otra parte, puesto que el artículo 105 señala las hipótesis en las que se pueden presentar acciones de inconstitucionalidad y de controversia constitucional, pero no el procedimiento a seguir, se hace necesaria una ley que haga plenamente eficaz este dispositivo constitucional. En general, cabría incluir aquí a las disposiciones constitucionales que para su plena eficacia requieren de la presencia de las denominadas "leyes orgánicas".

22 Corte Constitucional, Sentencia C-415 de 2012, 6 de junio de 2012.

23 Rodríguez, op. cit., p. 10. 
En México se pueden identificar, entre otras, las siguientes normas constitucionales de principio: "Está prohibida la esclavitud en los Estados Unidos Mexicanos", "El varón y la mujer son iguales ante la ley", "A ninguna persona podrá impedirse que se dedique a la profesión, industria, comercio o trabajo que le acomode, siendo lícitos", "A ninguna ley se dará efecto retroactivo en perjuicio de persona alguna”. En este caso es importante hacer notar que si bien es cierto que corresponde al legislador permanente concretar estos principios, ello no obsta para que, en caso de no hacerlo, sean los jueces quienes realicen esa labor de concreción, mediante su función de interpretación. Por ello es que las normas de principios necesitan de determinación o especificidad, pueden gozar de eficacia directa, mediante la intervención de los intérpretes, aunque en ningún instante éstos podrán sustituir al legislador en su labor.

Normas constitucionales programáticas: puesto que pueden llegar a confundirse, es preciso comparar éstas con las normas de principio, con el fin de reconocerlas: "las normas programáticas se refieren esencialmente a los aspectos político-sociales, mientras que los principios se refieren a la coherencia interna del ordenamiento, respecto a determinados supuestos iniciales: los programas miran al fin; los principios, al inicio de una acción normativa". También en este tipo de normas constitucionales encontramos buenos ejemplos en el sistema mexicano: en tanto que "Todo individuo tiene derecho a recibir educación" (norma de principio), "El Estado -Federación, Estados y Municipios-impartirán educación preescolar, primaria y secundaria” (norma programática); puesto que "Los niños y las niñas tienen derecho a la satisfacción de sus necesidades de alimentación, salud, educación y sano esparcimiento para su desarrollo integral" (norma de principio), "El Estado proveerá lo necesario para propiciar el respeto a la dignidad de la niñez y el ejercicio pleno de sus derechos" (norma programática).

No se debe perder de vista que, aunque se puedan clasificar de distintas maneras, las normas constitucionales, en tanto constitucionales son supremas todas y, en tanto, normas jurídicas, son coercitivas. Decir de una Constitución que tiene fuerza normativa significa que tal instrumento es eficaz, es decir, que los sujetos a él sometidos convierten a esa Constitución en motivo esencial de sus acciones. Siguiendo las ideas apuntadas sobre el Estado de derecho, cabe decir que una Constitución normativa es aquella que se convierte en regla de acción del poder político y de los individuos, no en instrumento de dominación de unos sobre otros. Por otra parte, en Colombia, las normas se clasifican en el siguiente orden ${ }^{24}$ :

24 La clasificación y conceptos de dicho orden son de obra de CASTRO (2004), p. 59. 
1. Normas declarativas o de principios: Proclamación de propósitos y afirmación de principios.

2. Normas instituyentes $\mathrm{u}$ organizadoras: Organización o funcionamiento de los poderes o funciones del Estado.

- Normas de estructura: Organizan los elementos del Estado y particularmente el poder.

- Normas de atribución de competencia: A cada función u órgano del Estado le atribuyen competencias, materias sobre las que debe actuar.

- Normas de procedimiento: Señalan cómo han de actuar los distintos órganos del Estado en el ámbito de sus competencias para ejercer las facultades que la Constitución les ha concedido.

3. Normas programáticas: Requieren ser reglamentados por ley para entrar en funcionamiento.

- Por su imperatividad: Según otorguen una facultad o impongan una obligación a los poderes constituidos.

- Programáticas optativas o no imperativas: Optativas para los poderes públicos y sólo confieren una facultad al legislador o autoridad.

- Programáticas de cumplimiento: Imponen una obligación de hacer con la que se debe cumplir.

- Por sus destinatarios: Depende a quién se dirige.

- Programáticas dirigidas al Legislador: A la Legislatura para que desarrolle el precepto programático constitucional a través de las leyes.

- Programáticas dirigidas a otras autoridades: Pueden dirigirse a cualquiera de los poderes constituidos.

- Por su discrecionalidad: Según sea reglamentado el encargo de desarrollo de la disposición constitucional.

- Programáticas que sólo encomiendan la regulación del tema: Otorga amplia discrecionalidad para el desarrollo del propósito constitucional.

- Programáticas que dan directrices sobre cómo debe ser la regulación: La propia norma establece claras directrices.

4. Normas operativas: Se aplican directamente.

- Por la conducta que establecen.

- Operativas permisivas: Autorizan conducta al Estado o a los particulares.

- Operativas preceptivas: Imponen deberes de acción u omisión.

- Operativas prohibitivas: Impiden ciertos comportamientos.

- Operativas punitivas: Establecen una sanción.

- Por la posibilidad de ser limitadas. 
- Operativas irrestrictas: No pueden limitarse ni regularse por normas complementarias.

- Operativas de eficacia restringida: Cláusulas reglamentables dentro de las pautas del bien común y razonabilidad.

\section{Omisión legislativa como conducta pasiva (no hacer)}

Para impugnar la omisión legislativa o reglamentaria debe demostrarse que el deber de actuar de la autoridad en cierto sentido existe, esto es, que un mandato legal obliga a una autoridad a expedir una disposición de carácter general; y quien tenga interés legítimo puede acudir a reclamar el inactuar de la autoridad.

\section{Clasificación de la omisión legislativa}

La clasificación más clásica es la planteada por el magistrado del Tribunal Constitucional alemán W. Wessel, la cual ha sido objeto de estudio por demás constitucionalistas y tratadistas. Para Wessel, la omisión legislativa absoluta: es aquella que presenta una ausencia total de la norma que debería regular una determinada situación jurídica fijada constitucionalmente. Mientras que en la omisión legislativa relativa, el legislador, al propulsar la norma para "obedecer" el mandato "constitucional", favorece a ciertos grupos y olvida a otros o acuerda ventajas a unos que no son dispensadas a otros, generando tentativamente las hipótesis a ser refundadas siempre en la siguiente fórmula: habrá omisión relativa toda vez que en el cumplimiento del mandato constitucional el órgano legislativo encargado de efectivizarlo quiebre en forma no intencional, pero produciendo un resultado discriminatorio y/o arbitrario el principio de igualdad. ${ }^{25}$ Así mismo, explica la procedibilidad de una demanda de constitucionalidad en ambas omisiones; por un lado, en la absoluta se niega toda posibilidad de instaurar dicha demanda; en cambio, en la relativa sí sería fiscalizable en tanto que implica la vulneración inmediata por el legislador de un derecho fundamental. ${ }^{26}$

Otra clasificación que se encuentra es la omisión formal y material, la formal es aquella que supone que el legislador ha adoptado una posición total o parcialmente inactiva respecto del encargo que requiere ser desarrollado. La omisión material consiste en la inactividad que vulnera, específicamente, el principio de

BAZAN (2017), p. 105.

26 WESSEL (1952), p. 164. 
igualdad, debido a que el órgano legisferante olvida igualar la norma a todos los grupos que prevé. ${ }^{27}$

En contraste con estas clasificaciones, Néstor Pedro Sagüés las clasifica en dos formas distintas, la inconstitucionalidad por omisión por mora y la inconstitucionalidad por negación, haciendo referencia a la misma omisión relativa. La primera se divide en tres factores:

A. Inercia en adoptar una decisión concreta, como, por ejemplo, abstenerse de poner en libertad a alguien cuya detención ya no tiene ningún objeto al haber concluido legalmente.

B. Mora en la ejecución que se produce cuando, habiendo una decisión tomada, ésta no se cumple. Un ejemplo de esto lo tenemos en el caso de una pensión ya otorgada, pero que no se paga.

C. Tardanza en la producción de normas generales, también conocida como inconstitucionalidad legislativa; el caso más frecuente de esta modalidad, según Sagüés, es el ocio en el que incurre el legislativo al omitir reglamentar aquello que requiere de ulterior desarrollo normativo.

En cuanto a la inconstitucionalidad por negación o inconstitucionalidad por omisión relativa, es aquélla en donde el órgano legislativo incurre en una exclusión arbitraria de ciertos beneficios en perjuicio de un grupo de personas. ${ }^{28}$

En México, la Suprema Corte de Justicia de la Nación mediante jurisprudencia $^{29}$ realizó una clasificación acerca de la inconstitucionalidad por omisión legislativa, donde estableció cuatro categorías atribuibles a las obligaciones constitucionales del legislador:

A. Omisiones absolutas en competencias de ejercicio obligatorio, cuando el órgano legislativo tiene la obligación o mandato de expedir una determinada ley y no lo ha hecho.

B. Omisiones relativas en competencias de ejercicio obligatorio, cuando el órgano legislativo emite una ley teniendo una obligación o mandato para hacerlo, pero le concreta de manera incompleta o deficiente.

C. Omisiones absolutas en competencias de ejercicio potestativo, en las que el órgano legislativo decide no actuar debido a que no hay ningún mandato $\mathrm{u}$ obligación que así se lo imponga.

27 Fernandez (1998), p. 60.

28 SAGUÉs, p. 606.

29 Sentencia Corte Suprema de Justicia de la Nación, P./J. 11,2006 No 175872, febrero de 2006. 
D. Omisiones relativas en competencias de ejercicio potestativo, en las que el órgano legislativo decide hacer uso de su competencia potestativa para legislar, pero al emitir la ley lo hace de manera incompleta o deficiente.

Por otro lado, César Astudillo la clasifica en omisión evidente y omisión oculta. La primera se refiere a la ausencia de una disposición frente a un mandato de la Constitución. La segunda, se actualiza cuando lo que existe es la carencia de una norma que lesiona los contenidos constitucionales y que no es posible identificar a "simple vista", sino sólo a través de la intervención de un juez. ${ }^{30}$

Por último, dentro de este artículo, se encuentra la distinción por incidencia, que se presenta cuando la omisión legislativa afecta derechos fundamentales y cuando no los afecta. ${ }^{31}$

Desde esta perspectiva, no existe unificación dentro del territorio mexicano acerca de cómo concretamente está establecido su uso, protección y alcances, es por esto que se desarrollará más adelante un acápite sobre la regulación que a nivel local se ha ido implementando como medio de control.

Por otra parte, en Colombia, jurisprudencialmente se han desarrollado dos clases de omisiones: la omisión absoluta, y la omisión relativa; la primera se constituye cuando hay una falta total de una disposición de desarrollo legislativo de un determinado precepto constitucional; mientras que, en la segunda, el legislador ha expedido la ley, pero en ella solamente ha regulado algunas relaciones dejando por fuera otros supuestos análogos, con clara violación del principio de igualdad. ${ }^{32}$

En concepto de la Corte Constitucional, la omisión legislativa relativa se presenta cuando el legislador incumple una obligación derivada de la Constitución, que le impone adoptar determinada norma legal; y la omisión legislativa absoluta se presenta en caso de falta absoluta de regulación legal, cuando no pesa sobre el legislador el deber constitucional de proferir una determinada norma. ${ }^{33}$

Se puede entender que la omisión legislativa relativa se puede dar como una situación discriminatoria y, por lo tanto, una vulneración al derecho a la igualdad; sin embargo, la Corte Constitucional estableció que no es la única circunstancia en que ésta se puede constituir, siendo posible observar situaciones en las que el precepto ignora algún otro tipo de elemento normativo, que conforme a la disposición superior

30 Astudillo (2007), p. 316.

31 Distinción central y principal en el estudio del texto desarrollado.

32 Corte Constitucional, Sentencia C-543/1996, 16 de octubre de 1996.

33 Corte Constitucional, Sentencia C-173/2010, 10 de marzo de 2010. 
debe considerarse imperativo. Dentro de esas exigencias constitucionales pueden mencionarse la de considerar determinados objetivos al momento de regular una materia, la de incluir ciertas etapas esenciales en la regulación de un procedimiento, la de brindar instancias de participación a algunos sujetos específicos previamente a la decisión sobre temas que pueden afectarlos, y otras semejantes. ${ }^{34}$

\section{MÉXICO}

México es una federación 35 integrada por 31 entidades federativas y la ciudad de México, las cuales están facultadas para regular su régimen interno, de esta forma hay 31 Constituciones locales ${ }^{36}$ y la Constitución Política de los Estados Unidos Mexicanos.

El artículo 115 de la CPEUM dispone: "Los Estados adoptarán, para su régimen interior, la forma de gobierno republicano, representativo, democrático, laico y popular, teniendo como base de su división territorial y de su organización política y administrativa, el municipio libre...".

A nivel federal no ha sido implementada la acción por omisión legislativa; el artículo 105 de la CPEUM prevé como medios de control constitucional: las controversias constitucionales y las acciones de inconstitucionalidad, ${ }^{37}$ pero dentro de éstas tampoco aparece de forma textual la posibilidad de reclamar mediante dichos medios de control las omisiones que vulneren derechos humanos.

Sin embargo, a nivel local ${ }^{38}$, la acción por omisión legislativa como un proceso autónomo con características propias, se ha establecido en algunas entidades de la federación como un medio de control constitucional, ésta se encuentra establecida en las Constituciones estaduales de Tlaxcala, Veracruz ${ }^{39}$, Chiapas, Quintana Roo,

34 Corte Constitucional, Sentencia C-314/2009, 5 de mayo de 2009.

35 A pesar de que México está constituida formalmente como una federación, es fundamentalmente un sistema de facto centralista, en proceso lento de descentralización. Las políticas más trascedentes son impuestas o copiadas por los Estados desde el centro. Lo que ha hecho que las Constituciones locales pasen desapercibidas e, inclusive, en las instituciones superiores de educación, éstas no son contempladas con los programas de estudio, mientras que la federal es la "única" que se estudia.

36 Actualmente se encuentra en proyecto la Constitución de la ciudad de México.

37 Para mayor información, consultar "Controversias constitucionales y acciones de inconstitucionalidad. Diferencias entre ambos medios de control constitucional". https://sjf.scjn.gob.mx/SJFSist/Documentos/ Tesis/1000/1000471.pdf.

38 Para mayor información, consultar FerRer MAC-GREgor, Derecho procesal constitucional local en México.

39 Veracruz fue la primera entidad que la introdujo la acción por omisión legislativa en el 2000. 
Coahuila, Estado de México, más las que se acumulen, sin embargo, en cada caso es regulado de forma heterogénea.

\section{La acción por omisión legislativa en entidades de México}

A continuación, en forma sintetizada, se reproducen las particularidades con las que se ha implantado la acción por omisión legislativa en México, en donde se puede apreciar la forma heterogénea de su regulación.

\section{Justicia constitucional en Chiapas}

En las entidades o provincias del país ha quedado rezagada la independencia del Poder Judicial respecto del Ejecutivo, casi congelada, en contraste con los pasos aparentemente dados a nivel federal o al menos sin una desfachatez palpable en las intromisiones. Los gobiernos en turno no dejan de reflejar e impactar su hegemonía sobre la administración de justicia. Cuando los gobernantes terminan su encargo, pretenden convertir al Poder Judicial en una isla, donde puedan todavía influir y les sirva como capa protectora de impunidad. Pero poco les dura el gusto, decreto mata decreto, la nueva oleada gubernamental no tarda en destruir la barrera ficticia invocada al amparo de los ideales de Montesquieu, y se imponen los intereses del monarca nuevo.

La justicia constitucional en Chiapas no es ajena a ello, más bien ha sido un arma no para frenar los actos inconstitucionales, sino para desarropar a los contrarios y cobijar a los grupos de burócratas del Ejecutivo en turno.

La justicia constitucional no ha sido más que una ficción hasta ahora. No responde a una necesidad. Ha sido implantada artificialmente, ajena al concierto social de la vida de la entidad. En contraste, la tarea de los juzgados de la justicia no constitucional ha sido reducida, por ejemplo, en los juzgados civiles de Tuxtla Gutiérrez las coordinaciones de actuarios han desaparecido; se ha acortado el número de tres a dos actuarios por juzgado; se han extirpado las oficialías de partes de los juzgados civiles y familiares.

\subsection{La acción por omisión legislativa en Chiapas}

La acción por omisión legislativa está regulada por la Ley de Control Constitucional del Estado de Chiapas (en lo posterior, LCC), publicada en el Periódico Oficial del Estado el 27 de noviembre de 2002; la LCC conformada por 101 artículos y uno transitorio, es reglamentaria, a partir de la última reforma de 2014 
de la Constitución Política del Estado de Chiapas (en lo sucesivo, CPECH) de los artículos 63 y 64.

La LCC establece en la parte del considerando que el objetivo primordial de la acción por omisión legislativa es la de garantizar que el Poder Legislativo como ente público del Estado cumpla con su deber de dotar a la comunidad de la cual emana las leyes y disposiciones legales que permitan la armónica convivencia de los miembros de ésta. La acción por omisión legislativa tiene por objeto también evitar que el legislador ejerza su poder en contravía del sistema axiológico de la Constitución o de los derechos fundamentales de cada uno de los habitantes del territorio, de esta forma surge la necesidad no sólo de controlar la constitucionalidad de sus actos sino también de garantizar que la comunidad [no] sufra algún perjuicio por parte del legislador al actuar al margen del derecho constitucional y en violación del mandato claro del constituyente.

En Chiapas, el miércoles 6 de noviembre de 2002 se publicó en el Periódico Oficial del Estado la reforma constitucional que transformó al Poder Judicial local. Se crearon instrumentos jurídicos en materia de justicia constitucional provincial, como existen en los Estados de Chihuahua, Coahuila, Tlaxcala, Veracruz y Estado de México; sin que en estas entidades haya identidad entre los mecanismos legislados.

\subsection{Procedencia de la omisión legislativa en Chiapas}

Procede la acción por omisión legislativa cuando el Congreso no resuelva alguna iniciativa de ley o decreto dentro de los términos que establezca la Legislación respectiva y que dicha omisión afecte el debido cumplimiento de la CPECH. (a.97 LCC).

Por disposición constitucional le corresponde al Legislativo la elaboración de leyes, tratándose de las normas constitucionales, sobre todo de aquellas de eficacia indirecta: las que "necesitan ser actuadas o concretadas a través de una posterior actividad normativa”. En este orden de ideas ante la obligación de hacer, cuya fuente es la norma suprema, frente al descuido de quien está encargado, es evidente que existe una transgresión a la Constitución, que requiere un mecanismo jurisdiccional para que pueda acatarse. La vigencia de una Constitución no puede depender de la voluntad de un órgano constituido frente a la problemática que plantea la inactividad legislativa del Poder Legislativo. La Constitución es la base del sistema normativo jurídico. Esto es así, porque este instrumento establece los mecanismos de creación normativa y los órganos facultados para intervenir 
en dichos mecanismos. La Constitución no sólo crea al Estado y lo divide en órganos, sino que le atribuye a dichos órganos diversas facultades y obligaciones, de la misma forma que, al regular la relación entre los individuos y el Estado, consagra derechos y obligaciones de los primeros y límites a la acción del segundo.

Están facultados para interponer la acción por omisión legislativa:

a) El Gobernador del Estado;

b) Cuando menos la tercera parte de los miembros del Congreso ${ }^{40}$, y

c) Cuando menos la tercera parte de los ayuntamientos.

Es significativo señalar que la LCC al regular la acción por omisión legislativa no cuenta con un capítulo específico que disponga sobre la ejecución de la sentencia, lo que sí sucede con las controversias constitucionales y acciones de inconstitucionalidad, para vincular al Congreso a la resolución, cuando éste persista en la omisión, lo que crea una incertidumbre jurídica y evidencia la poca eficacia de este medio de control.

Para que proceda esta acción abstracta, toda vez que no se desprende de un caso concreto, no debe ser una simple omisión, sino que a consecuencia de ese no hacer, provoque la ineficacia de los postulados de la Constitución. "Si la inexistencia de ley o decreto no impide la correcta aplicación de la norma constitucional no habrá omisión que se pueda tachar de contraria a la Carta Magna". ${ }^{41}$

El órgano jurisdiccional creado para conocer de los medios de control constitucional inicialmente fue la Sala Superior incrustada en el Poder Judicial, integrada por 10 magistrados.

A partir de 2007, una de las novedades es que se faculta para interponer la acción por omisión legislativa a cuando menos el 5\% de los ciudadanos inscritos en el padrón electoral ${ }^{12}$. Además, a diferencia de la reforma de 2002, la acción por omisión legislativa que fungió como una especie de derecho de petición no vinculatoria, ahora hay una interesante modalidad, ya que la resolución que emita el Tribunal Constitucional que decrete la existencia de omisión legislativa,

\footnotetext{
40 Las leyes que son aprobadas en el Congreso generalmente son iniciativas del Ejecutivo, poco o nada se debate, menos es que sea utilizada la acción por omisión legislativa por ninguna minoría, por lo que no se puede evaluar el criterio objetivo (el número necesario para su promoción), ni que se haya analizado la procedencia de un requisito "subjetivo" al votar en contra de un proyecto de una ley específica.

41 Rodríguez, op. cit., p. 152.

42 De acuerdo con el padrón electoral, Chiapas tiene registrados a 2. 492.396 ciudadanos (cifra actualizada al 28 de febrero de 2005). Por lo que se requiere de 124.619 para promover la acción por omisión legislativa, cifra absurda y sin sentido.
} 
surtirá sus efectos a partir de su publicación en el Periódico Oficial del Estado; en dicha resolución se determinará como plazo un período ordinario de sesiones del Congreso del Estado, para que éste resuelva la omisión correspondiente, y tratándose de legislación que deba de aprobarse por el Congreso, por mandato de la CPEUM o de la CPECH, si el Congreso no lo hiciere en el plazo fijado, el Tribunal Constitucional lo hará provisionalmente en su lugar y dicha legislación estará vigente hasta que el Congreso subsane la omisión legislativa.

Esta facultad extraordinaria de legislar transitoriamente del Tribunal Constitucional de Chiapas surge ante la omisión legislativa y de la ejecución de la sentencia.

Es significativo mencionar que el órgano jurisdiccional que antes era competente para conocer y resolver este tipo de procedimientos, era la Sala Superior, con la reforma de 2007 se suprime y cambia a un Tribunal Constitucional, de siete magistrados que integraban a la primera, pasa a tres y en 2008 a cinco.

El Tribunal Constitucional es el órgano rector de los criterios jurídicos de interpretación conforme a la Constitución Política del Estado de Chiapas y de las leyes que de ella emanen; garantizar la supremacía y control de la Constitución Política del Estado mediante su interpretación; siempre y cuando no sea contraria a lo establecido en el artículo 133, de la CPEUM, ni a la jurisprudencia de la SCJN; conocer de las controversias constitucionales, acciones de inconstitucionalidad, acciones por omisión legislativa y de las cuestiones de inconstitucionalidad, entre otras.

\section{Veracruz}

El Estado de Veracruz modificó su Constitución Política en el 200043, con la cual incluyó como medios de control constitucional a las controversias constitucionales, a las acciones de inconstitucionalidad y a las acciones por omisión legislativa.

Se prevén instancias de los particulares como el juicio de protección de derechos humanos y la impugnación contra las resoluciones del Ministerio Público (MP) sobre la reserva de la averiguación previa, el no ejercicio de la acción penal y las resoluciones de sobreseimiento que dicten los jueces con motivo de las peticiones de desistimiento que formule el MP.

Se encuentra regulada la consulta judicial cuyo objetivo es dar respuesta a las peticiones formuladas por los demás tribunales y jueces a la Sala Constitucional,

43 Decreto publicado en la Gaceta Oficial del Estado de Veracruz del 3 de febrero de 2000. 
cuando tengan duda sobre la constitucionalidad o aplicación de una ley local, en el proceso sobre el cual tengan conocimiento. Las peticiones tendrán efectos suspensivos y deberán ser desahogadas en un plazo no mayor de treinta días naturales.

Las acciones por omisión legislativa proceden cuando se considere que el Congreso no ha aprobado alguna ley o decreto y que dicha omisión afecte el debido cumplimiento de esta Constitución, que interponga: a) El Gobernador del Estado, o b) Cuando menos la $3^{a}$ parte de los ayuntamientos.

La resolución determinará un plazo que comprenda dos períodos de sesiones ordinarias del Congreso del Estado, para que éste expida la ley o decreto de que se trate la omisión. Si transcurrido este plazo no se atendiere la resolución, el Tribunal Superior de Justicia dictará las bases a que deban sujetarse las autoridades, en tanto se expide dicha ley o decreto.

El Estado de Veracruz cubre gran parte de la disputa constitucional que abarca el territorio mexicano, los mecanismos empleados tienen alto grado de efectividad, en el sentido que se conforma con la orden dada a la autoridad omisa de que emita la normatividad faltante, sino que se intenta corregir esta violación constitucional de manera inmediata al facultar al Tribunal para que garantice el cumplimiento de los preceptos constitucionales, al menos temporalmente. ${ }^{44}$

\section{Tlaxcala}

Esta entidad incorporó la acción contra la omisión legislativa, otorgándole competencia al Pleno del Tribunal Superior de Justicia, para que prevea las acciones por omisión legislativa no sólo contra el Congreso, sino contra el gobernador y los ayuntamientos o consejos municipales, por la falta de expedición de las normas jurídicas de carácter general, a que estén obligados en términos de las Constituciones Políticas, de los Estados Unidos Mexicanos, del Estado y de las leyes. ${ }^{45}$

Las acciones por omisión legislativa tienen como consecuencia constreñir al órgano omiso a legislar. Conceder tres meses al órgano responsable para expedir la norma jurídica solicitada, el incumplimiento de la sentencia será motivo de responsabilidad. Dentro del artículo 81 de la Constitución de esta entidad, se estipulan y se regulan los medios para utilizar dicha acción, incluyendo que puede ser interpuesta por cualquier ciudadano que resida en la entidad.

44 Rangel (2008), p. 211.

45 Según el artículo 81 de la Constitución Política del Estado Libre y Soberano de Tlaxcala. 


\section{Coahuila}

La Constitución Política del Estado de Coahuila de Zaragoza prevé una disposición reglamentaria: Ley de Justicia Constitucional Local. Le corresponde al pleno del Tribunal Superior de Justicia de la entidad (local) conocer de los medios de control, consistentes en controversias constitucionales; acciones de inconstitucionalidad; cuestión de inconstitucionalidad, y omisión normativa. Un aspecto a destacar dentro de este ordenamiento interno es que se establece el control difuso ${ }^{46}$, cuando la autoridad jurisdiccional considere en su resolución que una norma es contraria a esta Constitución, con base en lo establecido por el artículo 133 de la CPEUM deberá declarar de oficio su inaplicabilidad para el caso concreto. En este supuesto, el tribunal superior de justicia podrá revisar la resolución. En consonancia con lo anterior, la Ley de Justicia Constitucional Local para este Estado, en su artículo 65 dispone que, precisamente con base en este control difuso, los jueces ordinarios tienen la facultad de analizar la inconstitucionalidad por omisión legislativa. ${ }^{47}$

En las acciones de inconstitucionalidad cualquier persona puede instar el procedimiento a través del organismo protector de los derechos humanos, cuando se trate de violaciones a los derechos y garantías constitucionales; así como por organismos públicos autónomos y partidos políticos.

\section{Quintana Roo}

Se constituyó la Sala Constitucional y Administrativa dentro del Poder Judicial local, a la cual le compete la sustanciación de los medios de control constitucional; de los juicios administrativos y fiscales; resolver la contradicción de tesis; resolver los recursos por las determinaciones de no ejercicio de la acción penal y reserva de la averiguación previa, así como del sobreseimiento que dicte un juez a petición del MP; de los asuntos en materia laboral, burocrática y conflictos sindicales que agrupan a trabajadores del Estado o municipios; sin embargo, es el Pleno del tribunal superior de justicia quien resuelve las controversias constitucionales; acciones de inconstitucionalidad; acciones por omisión legislativa, teniendo ésta, en caso de ser fundada la pretensión, que en la resolución se determinará un plazo

\footnotetext{
46 Se encuentra reglamentado a pesar de que, a nivel federal, la Corte Suprema de Justicia de la Nación ha establecido en varias ocasiones que dentro del territorio mexicano no es aplicable.

47 Rangel (2008), p. 215.
} 
para que se expida la ley o decreto de que se trate la omisión, a más tardar en el período ordinario que curse o el inmediato siguiente del Congreso del Estado; pudiendo disminuir este plazo cuando el interés público lo amerite.

De acuerdo con la Ley Reglamentaria de los artículos 104 y 105 de la Constitución Política del Estado Libre y Soberano de Quintana Roo, dispone que tendrán el carácter de parte en las acciones por omisión legislativa: I. Como actor el Gobernador del Estado o un Ayuntamiento del Estado; II. Como demandado el Congreso del Estado; III. Como tercero interesado el Gobernador del Estado; el Procurador General de Justicia del Estado o cualquier órgano que pudiera ser afectado por la sentencia que llegare a dictarse.

\section{Tabasco $0^{48}$}

Existe una iniciativa legislativa para crear la Sala Constitucional, la cual estará integrada por cinco magistrados que conformarán el pleno y resolverán los medios de impugnación constitucionales locales por mayoría de votos.

Entre los medios de control constitucional se prevé el juicio de controversias constitucionales locales; el juicio de acciones de inconstitucionalidad local; el juicio de acción por omisión legislativa, y el juicio de derechos humanos fundamentales del Estado de Tabasco.

Las acciones por omisión legislativa podrán ser formuladas por: los ciudadanos, magistrados o jueces del Estado, el Titular de la Comisión Estatal de Derechos Humanos, el Consejero Presidente del Instituto Estatal y de Participación Ciudadana de Tabasco, cuando dichas omisiones legislativas afecten derechos fundamentales. Y se pronostica crear una ley especial denominada: Ley de Control y Defensa de la Constitución Política del Estado de Tabasco.

Es por esto que es menester hacer mención al siguiente $\operatorname{caso}^{49}$, donde se presenta una omisión legislativa en el territorio mexicano, como ejemplo al tema que se aborda: el día 25 de septiembre del año 2002, el Partido de la Revolución Democrática interpuso la acción de inconstitucionalidad, impugnando los artículos 7, 12, 30, 31, 38 y 49 de la Ley Orgánica del Instituto Electoral del Estado de Quintana Roo, considerando que eran violatorios a la CPEUM en su artículo 116, en cuanto a que las Constituciones y leyes estatales garanticen

48 Ver MarTíneZ (2017).

49 Acción de inconstitucionalidad 27/2002, Semanario Judicial de la Federación y su Gaceta, marzo de 2003. 
que la función electoral se rija por el principio de certeza; en virtud de que no se encuentra establecido el plazo cierto y determinado para que el legislador local haga el nombramiento del consejero presidente sustituto del Instituto Electoral, manifestando que ni la Ley Orgánica ni Constitución local estipulan dicho término. En este caso se puede evidenciar una omisión legislativa relativa, dado que sí se encuentra regulado el tema en específico, pero se omitió establecer el término para el nombramiento, generando un vacío normativo y un perjuicio. La Suprema Corte de Justicia de la Nación en este caso declaró procedente la acción de inconstitucionalidad, sosteniendo que, al omitirse dicha disposición, se viola la Constitución; igualmente requirió al Congreso del Estado de Quintana Roo para que lleve a cabo la adecuación de los numerales en cuestión. ${ }^{50}$

\section{Juicio de amparo}

Dentro de este acápite se esclarecerá al juicio de amparo como medio de control viable para acceder a la justicia cuando se presente una vulneración de los derechos humanos por parte de una omisión legislativa; éste se consagra como un control de constitucionalidad en el sentido que la omisión por parte del legislador es una violación directa a la Constitución Política, por ende, se materializa la vulneración de los derechos humanos. ${ }^{51}$

De igual modo, cuando la Constitución Política es explícita en imponer las obligaciones constitucionales, y se genere su abstención que implique o involucre un daño para una persona o colectivo, aquel que promueva un recurso judicial que le permita controlar los perjuicios realizados a sus derechos, deberá estar legitimado para hacerlo. 52

El juicio de amparo en México existe desde 1841 (Yucatán) a nivel estatal y en el ámbito federal a partir de la Constitución de $1857^{53}$ como medio de control

\footnotetext{
50 RaNGel (2008), p. 221.

51 Se funda cuando se presenta un desconocimiento normativo por parte del legislador, esto es, porque la Constitución Política le atribuye obligaciones y deberes de protección que debe cumplir y, al omitirlo, genera un vacio normativo, que conlleva la vulneración de derechos humanos; dado que no se busca la protección de ésta, sino la protección de los derechos humanos consagrados allí.

52 Rodríguez (1998), p. 34.

53 En la vigencia del artículo 98 de esta Constitución, surgieron graves problemas jurídicos por no existir una ley reglamentaria de las facultades otorgadas a la SCJN, se llegó a decir que al no haber ley reglamentaria para sustanciar controversias constitucionales, los Estados carecían de derecho para entablar estos conflictos. GONZÁLEZ, (1993), p. 13.
} 
constitucional de protección de derechos fundamentales, garantías individuales o derechos humanos reservado exclusivamente a los particulares. Hay distintas clases para promover el amparo, pero principalmente se tratará el amparo denominado "amparo-garantías", que se presenta cuando la violación de garantías proviene de actos de autoridad. 54

La CPEUM fue reformada en el 2011, esencialmente, el primer capítulo que se refiere a los derechos humanos y en materia de juicio de amparo; antes de estas modificaciones el Pleno de la Suprema Corte de Justicia de la Nación (SCNJ) había determinado que el juicio de amparo era improcedente para cuestionar la inconstitucionalidad por omisión legislativa o reglamentaria ${ }^{55}$, por "la imposibilidad jurídica de analizar tales cuestionamientos deriva de que conforme al principio de relatividad que rige en el juicio de amparo", criterio superado a raíz del cambio de la CPEUM, hoy es posible que este medio de control de los particulares y no los órganos de gobierno, impugnar como acto reclamado, y no como un proceso autónomo, la omisión de la creación de normas.

En este sentido encontramos diversos criterios de los tribunales colegiados de circuito:

Omisión legislativa o reglamentaria. Hipótesis en que es procedente el amparo indirecto. El Pleno de la Suprema Corte de Justicia de la Nación sostuvo la tesis aislada de la improcedencia del juicio de amparo, cuando se impugna la omisión de la autoridad para expedir disposiciones de carácter general porque, en esos casos, podrian darse efectos generales a la ejecutoria vinculando no sólo al quejoso y a las responsables, sino a todos los gobernados y autoridades relacionadas con la norma creada, contraviniendo el principio de relatividad de las sentencias. Dicho criterio fue emitido antes de la reforma constitucional en materia de derechos humanos de 6 de junio de 2011, asi como del decreto por el que se expidió la nueva Ley de Amparo de 2 de abril de 2013 por lo que, adminiculando ambas reformas, actualmente es factible considerar que el amparo es procedente cuando se reclama la omisión legislativa o reglamentaria, por lo menos, cuando hay un mandato constitucional o legal que obligue a una autoridad y éste no se ha ejecutado. En esa circunstancia, el juicio de amparo si es procedente cuando se trate de una omision

54 Biblioteca Jurídica Virtual del Instituto de Investigaciones Jurídicas de la UNAM, https://archivos. juridicas.unam.mx/www/bjv/libros/7/3084/4.pdf.

55 Tesis: P. LXXX/99, Semanario Judicial de la Federación y su Gaceta, Tomo X, noviembre de 1999, p. 40. 
legislativa o reglamentaria, porque en ese supuesto no se pretende satisfacer un interés particular, sino uno legitimo para el cumplimiento de un mandato legal ya existente. 56

Omisión legislativa. Su concepto. Pueden darse deficiencias dentro del proceso legislativo que producen una falla en el mandato constitucional, ya sea derivado de descuido, olvido o insuficiencia en la creación de la norma o legislación sobre determinados rubros. En este sentido, la omisión legislativa puede definirse como la falta de desarrollo por parte del Poder Legislativo, durante un tiempo excesivo, de aquellas normas de obligatorio y concreto desarrollo, de forma que impide la eficaz aplicación y efectividad del texto constitucional, esto es, incumple con el desarrollo de determinadas cláusulas constitucionales, a fin de tornarlas operativas, y esto sucede cuando el silencio del legislador altera el contenido normativo, o provoca situaciones contrarias a la Constitución. ${ }^{57}$

El artículo $1^{\circ}$ de la CPEUM dispone la obligación a todas las autoridades, en el ámbito de sus competencias de promover, respetar, proteger y garantizar los derechos humanos de conformidad con los principios de universalidad, interdependencia, indivisibilidad y progresividad, lo que constriñe a los órganos jurisdiccionales a otorgar el servicio de acceso a la justicia de manera amplia y efectiva.

Omisión legislativa o reglamentaria. Su reclamo no constituye un motivo manifiesto e indudable de improcedencia de la demanda de amparo. A partir de la reforma constitucional de 6 de junio de 2011 se prevé, expresamente, la obligación de las autoridades de garantizar los derechos humanos de conformidad con los principios de universalidad, interdependencia, indivisibilidad y progresividad, mientras que el articulo 17 de la Constitución Politica de los Estados Unidos Mexicanos garantiza el acceso a una tutela judicial efectiva. En ese sentido, se concluye que no constituye un motivo manifiesto e indudable de improcedencia de la demanda de amparo, que se reclamen omisiones legislativas o reglamentarias, pues para advertir si existen o no, el Juez de Distrito debe revisar: a) si hay un mandato normativo expreso que implique el actuar de la autoridad en la forma que se reclama; b) si se configura la omisión del cumplimiento de tal obligación, y c) si esa abstención vulnera un derecho humano. Lo anterior requiere un análisis que debe realizarse en la sentencia y no en un acuerdo de desechamiento, por lo que no es un motivo notorio y manifiesto de improcedencia. ${ }^{58}$

56 Tesis: I.18o.A.11 K (10a.), Semanario Judicial de la Federación y su Gaceta, Libro 35, octubre de 2017, Tomo IV, p. 2995.

57 Tesis: I.4o.A.21 K (10a.), Gaceta del Semanario Judicial de la Federación, Instancia: Tribunales Colegiados de Circuito, Libro 1, diciembre de 2013, Tomo II, p. 1200.

58 Tesis: I.18o.A.10K, Semanario Judicial de la Federación y su Gaceta, Libro 35, octubre de 2017, Tomo IV, (10a.), p. 2996. 
Un elemento importante para determinar si hay o no omisión legislativa o reglamentaria es el tiempo transcurrido entre la vigencia de norma constitucional que requiere para su desarrollo de la ley o reglamento o, en su caso, el vencimiento del plazo otorgado por el constituyente, en el primer supuesto es posible por analogía hablar del plazo razonable y utilizar los criterios de la Corte Interamericana de Derechos Humanos, ya que en la práctica cada caso presenta ciertas particularidades:

El articulo 8.1 de la Convención también se refiere al plazo razonable. Este no es un concepto de sencilla definición. Se pueden invocar para precisarlo los elementos que ha señalado la Corte Europea de Derechos Humanos en varios fallos en los cuales se analizó este concepto, pues este articulo de la Convención Americana es equivalente en lo esencial, al 6 del Convenio Europeo para la Protección de Derechos Humanos y de las Libertades Fundamentales. De acuerdo con la Corte Europea, se deben tomar en cuenta tres elementos para determinar la razonabilidad del plazo en el cual se desarrolla el proceso: a) la complejidad del asunto; b) la actividad procesal del interesados, y c) la conducta de las autoridades judiciales. 59

No obstante, la pertinencia de aplicar esos tres criterios para determinar la razonabilidad del plazo de un proceso depende de las circunstancias de cada caso. Además, en este tipo de casos, el deber del Estado de satisfacer plenamente los requerimientos de la justicia prevalece sobre la garantía del plazo razonable [... $]^{60}$

La omisión legislativa o reglamentaria incide en dos principios: el de legalidad, máxime tratándose de derechos humanos de naturaleza social y económica que exigen prestaciones asignadas como obligaciones al Estado; $y$, el otro, el acceso a la justicia o la función jurisdiccional del Estado que requiere la reparación integral en caso de violación de derechos humanos, así se determina en el siguiente criterio:

Omisión legislativa. Notas distintivas. La omisión legislativa es la falta de desarrollo por parte del Poder Legislativo, durante un tiempo excesivo, de aquellas normas de obligatoria $y$ concreta realización, de forma que impide la eficaz aplicación del texto constitucional; esto es, incumple con el desarrollo de determinadas cláusulas constitucionales a fin de tornarlas operativas y esto sucede cuando el silencio del legislador altera el contenido normativo o provoca situaciones contrarias a la Constitución. De ello, se deduce que la

59 Corte IDH. Caso Genie Lacayo Vs. Nicaragua. Fondo, Reparaciones y Costas. Sentencia de 29 de enero de 1997. Serie C No 30, Párrafo 77.

60 Corte IDH. Caso La Cantuta Vs. Perú. Fondo, Reparaciones y Costas. Sentencia de 29 de noviembre de 2006. Serie C No 162, Párrafo 149. 
nota distintiva de dich a figura juridica consiste en que la norma constitucional preceptiva ordena practicar determinado acto o actividad en las condiciones que establezca, pero el destinatario no lo hace en los términos exigidos, ni en tiempo hábil; asi, la omisión legislativa no se reduce a un simple no hacer, sino que presupone una exigencia constitucional de acción y una inacción cualificada. Lo anterior responde a que, para hacer efectivos los derechos fundamentales, existen dos principios a colmar, el primero llamado de legalidad que, tratándose de ciertos derechos fundamentales, especialmente los sociales, exige que ciertas prestaciones sean impuestas como obligaciones a los poderes públicos y no abandonadas al arbitrio administrativo, por lo que legislativamente es necesario se colmen sus presupuestos vinculantes e identifiquen con claridad los órganos y procedimientos; $y$, el segundo, es el jurisdiccional, imponiendo que las lesiones a los derechos fundamentales deben ser justiciables y reparadas, especialmente cuando se incide en el núcleo esencial de los derechos, o se desatiende el minimo vital que debe ser protegido y garantizado. En suma, es necesario que para obtener la efectividad de los derechos fundamentales se disponga de acciones judiciales conducentes a que sean aplicables y exigibles juridicamente, lo que requiere de una normativa jurídica adecuada. ${ }^{61}$

Es menester aclarar que para que el juicio de amparo sea procedente debe existir un mandato expreso, que obligue a la autoridad a legislar sobre un determinado punto, que constituya un interés legítimo. ${ }^{62}$

Para dejar más claro este punto, sobre la procedencia de medios de control cuando se presente una omisión legislativa, la tesis P./J. 5/2008 de la Suprema Corte de Justicia de la Nación estableció que la acción de inconstitucionalidad es improcedente contra la omisión de los Congresos de los Estados de expedir una ley, por no constituir una norma general que, por lo mismo, no ha sido promulgada ni publicada, los cuales son presupuestos indispensables para la procedencia de la acción. ${ }^{63}$ Lo anterior hace manifiesta la improcedencia de un medio de control sobre una omisión legislativa absoluta.

\section{COLOMBIA}

El incumplimiento de las obligaciones y deberes constitucionales a cargo del legislador ha generado que el ordenamiento jurídico colombiano prevea esas

61 Tesis: I.4o.A.22 K (10a.), Gaceta del Semanario Judicial de la Federación, Libro 1, diciembre de 2013, Tomo II, p. 1199.

62 Cruz (2017), p. 553.

63 Sentencia Suprema Corte de Justicia, No P./J. 5/2008, 1 de febrero de 2008. 
situaciones y cree mecanismos de solución y protección de garantías; es por esto que se ha establecido la posibilidad de juzgar e impugnar las omisiones legislativas presentadas.

Antes de abordar el tema objeto de este artículo, es necesario establecer las siguientes aclaraciones ${ }^{64}$ :

Dentro del marco normativo colombiano, haciendo referencia a la Constitución Política ${ }^{65}$ en especial la omisión legislativa no se encuentra taxativamente, por lo tanto, no existe un medio de control para impugnar la conducta pasiva omisiva del legislador ${ }^{66}$. Así mismo, la Constitución Política no impone plazos para que el legislador tenga que cumplir en determinado tiempo la obligación de legislar.

\section{Procedencia de la omisión legislativa}

Para constituirse la omisión legislativa absoluta, como anteriormente se mencionó, el legislador no tiene que haber producido ninguna norma en relación con el tema en específico, es decir, que no hay regulación alguna sobre un tema dentro del ordenamiento jurídico interno. Al contrario, la omisión legislativa relativa, la Corte Constitucional ha establecido cinco elementos que deben concurrir para que esta omisión se presente: que exista una norma sobre la cual se predique necesariamente el cargo; que la misma excluya de sus consecuencias jurídicas aquellos casos que, por ser asimilables, tenían que estar contenidos en el texto normativo cuestionado, o que el precepto omita incluir un ingrediente o condición que, de acuerdo con la Constitución, resulta esencial para armonizar el texto legal con los mandatos de la Carta; que la exclusión de los casos o ingredientes carezca de un principio de razón suficiente; que la falta de justificación y objetividad genere para los casos

\footnotetext{
64 Corte Constitucional, Sentencia C- 543/1996, 16 de octubre de 1996.

65 En la época posmoderna, la Constitución se concibe como un estatuto reflexivo, que a través de ciertos procedimientos, del llamamiento a autorregulaciones, de sugerencias en el sentido de la evolución políticosocial, permite la existencia de una pluralidad de opciones políticas, la compatibilización de los disensos, la posibilidad de varios partidos políticos, la garantía del cambio a través de la construcción de rupturas (GOMES, 1993).

66 Sin embargo, mediante vía jurisprudencial se ha implementado la acción de inconstitucionalidad como medio de control para impugnar las omisiones legislativas.
} 
excluidos de la regulación legal una desigualdad negativa frente a los que se encuentran amparados por las consecuencias de la norma, y que la omisión sea el resultado del incumplimiento de un deber específico impuesto por el constituyente al legislador. ${ }^{67}$

\section{Improcedencia de la omisión legislativa}

Es pertinente aclarar que no toda omisión del legislador abre paso al control de constitucionalidad; la demanda de inconstitucionalidad por medio de la cual se alega una omisión legislativa relativa debe acusar el contenido normativo relacionado de forma específica con la omisión. Si la demanda recae sobre un conjunto indeterminado de normas o en ella se argumenta que se ha omitido la regulación de un aspecto particular o ella versa sobre normas de las cuales no emerge el precepto que el actor echa de menos, no podrá ser admitida. ${ }^{68}$ Los requisitos de procedencia de la omisión legislativa relativa deben cumplirse y tramitarse como la jurisprudencia colombiana lo ha expuesto, la norma debe ser específica, y la falta de regulación se debe demostrar con la afectación en particular, más adelante se expondrán varios ejemplos, para mayor claridad de este punto. Desde esta perspectiva, se evidencia que los legitimados por activa para alegar una omisión legislativa relativa debe ser el directamente afectado con la norma en cuestión en cada caso particular, de lo cual se desprende que el resarcimiento de la afectación podría versar en una de las pretensiones del proceso; sin embargo, se llevaría a cabo un proceso diferente, debido a que el que se explica en el presente artículo es la demanda de inconstitucionalidad. ${ }^{69}$

\footnotetext{
67 Corte Constitucional, Sentencia C-351/2013, 19 de junio de 2013.

68 Corte Constitucional, Sentencia C-1004/2007, 22 de noviembre de 2007.

69 En consecuencia, dependiendo del tipo de afectación se podría ejercer una acción de indemnización o una acción popular, debido a que cada una tiene diferentes requisitos para su procedencia. En el caso de la acción popular, ésta sería procedente genéricamente al tratarse de derechos e intereses colectivos, ya que esta acción se entiende como un mecanismo de protección (Corte Constitucional, sentencia C-215/99, 14 de abril de 1999); y en caso de la acción de indemnización, se vería involucrado un interés individual o particular.
} 


\section{Medios de control}

Dentro del ordenamiento jurídico se ha garantizado la protección de derechos humanos ${ }^{70}$ mediante el control de constitucionalidad, en el caso que nos atribuye, específicamente, es a través de la acción pública de inconstitucionalidad. La Corte Constitucional sostiene que, si bien permite realizar un control más o menos extenso de la labor legislativa, no autoriza la fiscalización de lo que el legislador genéricamente ha omitido, conforme a las directrices constitucionales. Lo que se pretende mediante la acción de inconstitucionalidad es evaluar si el legislador, al actuar, ha vulnerado o no los distintos cánones que conforman la Constitución. ${ }^{71}$ Es por esto que la Corte Constitucional es competente para conocer las demandas de inconstitucionalidad que se instauren en contra de las omisiones legislativas relativas $^{72}$; sin embargo, el trato y procedimiento que se da por el máximo órgano constitucional es diferente para la omisión legislativa absoluta, dado que si no hay actuación, no hay acto que comparar con las normas superiores; si no hay actuación, no hay acto que pueda ser sujeto de control, en otras palabras, la Corte Constitucional no es competente para pronunciarse sobre las demandas de inconstitucionalidad sobre las omisiones legislativas absolutas.

\section{Mecanismos para subsanar la omisión legislativa}

El objetivo del estudio de la omisión legislativa es la protección de los derechos humanos ${ }^{73}$ que se ven afectados y vulnerados cuando se presenta dicha omisión, y así mismo establecer qué medios de control pueden ser utilizados para que se resarzan los perjuicios y daños que se causen con la omisión; es por esto que la

\footnotetext{
${ }^{70}$ La importancia de los derechos humanos radica en que una de las realidades que más aflige a la humanidad es la constante presencia de conductas por las cuales una persona en contra de otra, vulnera gravemente sus derechos fundamentales, desde una perspectiva genérica (CUBIDES y BARRETO, 2017, p. 674).

71 Corte Constitucional, Sentencia C-543/96, 16 de octubre de 1996.

72 De conformidad con la sentencia C-1004/2007, por cuanto éstas tienen efectos jurídicos que pueden "presentar una oposición objetiva y real con la Constitución, la cual es susceptible de verificarse a través de una confrontación de los mandatos acusados y las disposiciones superiores".

73 Efectivamente, el compromiso de protección de los derechos humanos conlleva reglas básicas dentro de los Estados sobre las cuales se han establecido los mínimos necesarios para su goce efectivo, estos son: una pretensión de universalidad de reconocimiento a toda la humanidad, una interdependencia de todos los derechos, una condición de indivisibilidad y un deber de progresividad, conocida sobre todo por la prohibición de regresividad. (Cubides, Chacón y LAzCANo, 2015, p. 61).
} 
Corte Constitucional, para efecto de subsanar las omisiones legislativas relativas, ha empleado lo siguiente ${ }^{74}$ :

- Sentencia integradora: son aquellas que declaran la ilegitimidad constitucional de la previsión omitida que debería haber sido prevista por la ley para que ésta fuera constitucional. La Corte en estas sentencias no anula la norma acusa$\mathrm{da}$, sino que le agrega un contenido que la hace constitucional. Se incorpora un elemento nuevo al enunciado normativo, extendiendo la norma para que asuma un supuesto de hecho no contemplado en sus inicios. ${ }^{75}$

- Sentencia interpretativa o condicionada: con estas sentencias la Corte excluye la interpretación o interpretaciones que no se encuentran conforme a la Constitución. En esta clase de sentencias no se expulsa del ordenamiento jurídico, por cuanto su texto literal no es inconstitucional, sino lo que resulta contrario a la Constitución es la interpretación que se le imparte.

- Sentencia modulativa: La modulación del fallo constitucional se refiere a la adecuación teórico-jurídica de la norma infraconstitucional con la disposición superior, lo cual implica un pronunciamiento sobre las connotaciones políticas de la disposición bajo estudio. Sin embargo, la modulación se realiza en el terreno jurídico de la investigación, y el pronunciamiento sobre los efectos políticos es extraño al control que ejerce el juez constitucional. ${ }^{76}$

Por otro lado, en cuanto a las omisiones legislativas absolutas, dado que la Corte Constitucional no es competente para pronunciarse acerca de ellas, por las razones que se expusieron anteriormente, existe un mecanismo constitucional para que no se queden sin regulación dichas omisiones, denominado "exhorto constitucional”, el cual consiste en que el Congreso de la República se ocupe del análisis de la cuestión y de la expedición de una ley que, de manera sistemática y organizada, regule el tema en cuestión que la omisión legislativa absoluta abarca. ${ }^{77} \mathrm{La}$ Corte Constitucional aclara que el exhorto no debía ser visto como una ruptura de la división de los poderes, sino como una expresión de la colaboración de los mismos para la realización de los fines del Estado. ${ }^{78}$

\footnotetext{
74 Corte Constitucional, Sentencia C-038/2006, 1 de febrero de 2006.

75 Olano (2004), p. 8.

76 Corte Constitucional, Sentencia C.1153/2005, 11 de noviembre de 2005.

77 Corte Constitucional, Sentencia C-577/11, 26 de julio de 2011.

78 BAZÁN (2014), p. 208.
} 
A pesar de que el exhorto constitucional no se encuentra tipificado, la Corte Constitucional ha recurrido a este mecanismo con el propósito de que el Congreso de la República expida una ley de determinado tema respecto a una sentencia en particular. Desde esta perspectiva, el exhorto constitucional es una figura no positivizada, expresada jurisprudencialmente e investigada y conceptualizada desde la doctrina. En este sentido, la sentencia C-728 del 2009 cobra gran importancia a la hora de exponer genéricamente la utilización de dicho instrumento, la cual especifica que este se utilizará en dos escenarios constitucionales: (i) en los casos de las omisiones legislativas, y (ii) en los casos de modulación de los efectos en el tiempo de los fallos de la Corte Constitucional. ${ }^{79}$

Por lo pronto, es importante destacar que el exhorto constitucional aún es una figura que requiere de investigación y profundización, por lo cual, se expondrán sus principales características a partir de la investigación llevada a cabo en el presente artículo. La primera de ellas es la inexistencia de norma jurídica en relación con el tema en específico tratado en determinada sentencia; la segunda, es la urgencia con la que se pretende exhortar al Congreso para la expedición de dicha norma, la cual se relaciona con la tercera característica, que se vincula directamente con la inclusión de derechos fundamentales en el conflicto presentado en la sentencia y, finalmente, la postura de la Corte Constitucional que expresa su inhibición de pronunciarse acerca del tema en cuestión de la sentencia.

\section{Casos de omisiones legislativas}

En lo subsecuente del artículo se ejemplificarán dos casos: uno acerca de la omisión legislativa absoluta y el otro sobre la omisión legislativa relativa. En este orden de ideas, para hacer mención primeramente a la omisión legislativa absoluta, el caso se presentó por falta de legislación acerca del matrimonio civil y derechos de las parejas del mismo sexo dentro del ordenamiento jurídico colombiano, al no existir una ley que regulara dicho tema. Por lo cual el señor Carlos Andrés Echeverry interpuso demanda de inconstitucionalidad por omisión legislativa absoluta. La Corte Constitucional admitió que se presen-

79 Celemín (2017), p. 9. 
taba ese vacío normativo, declarándose inhibida por no ser competente, por contemplarse omisión legislativa absoluta, y dirigió un exhorto al Congreso de la República para que regulara el tema en cuestión.

Referente a la omisión legislativa relativa, se da el presente caso que se demanda el artículo $3^{\circ}$ de la ley No 1221 de 2008 que determina los responsables de la formulación de una política pública de fomento al teletrabajo, porque, según los accionantes, el legislador incurrió en una omisión legislativa relativa al omitir la participación de las organizaciones sindicales en la construcción de dicha política, con lo que se transgrede el pilar fundamental de la democracia participativa establecida en el Constitución, el principio de participación en la toma de decisiones por parte de quienes son afectados por una política pública y lo dispuesto en tratados internacionales que prevén la obligación de garantizar la participación de los trabajadores en asuntos laborales. La Corte concluyó que efectivamente la omisión legislativa relativa se configuraba por cuanto: existe un regulación incompleta, en un texto normativo preciso, existente y determinado del cual se deriva la omisión, el artículo $3^{\circ}$ de la ley No 1.221 de 2008 excluye a los trabajadores, en cabeza de los sindicatos, de la participación en la elaboración de la política pública del teletrabajo, olvidando que tanto la Constitución como la jurisprudencia constitucional han establecido el derecho a la participación de los sectores que se ven directamente afectados con dicha política, no existe razón suficiente que justifique la omisión relativa en la que incurrió el legislador, con el silencio del legislador se vulnera el derecho a la participación y pese a que existe un deber impuesto del Constituyente referido a las garantías que deben ser reconocidas a los trabajadores.

Con estos dos casos se evidencian fácilmente las omisiones en que incurre el legislador, y la actuación de la Corte Constitucional para subsanar dichas omisiones.

\section{Análisis comparativo MéXICO y Colombia}

Es importante destacar la principal diferencia entre México y Colombia, y es el régimen político. En México, el régimen político es república federal, por lo cual se evidencia tanto a lo largo de la investigación como en la tabla a continuación la división que se tiene a la hora de establecer las características de la omisión legislativa, en cuanto dicha división se debe a los diferentes Estados de México. Por el contrario, el régimen político en Colombia es república unitaria, estableciendo las características en general para todo el territorio nacional. 


\section{Tabla 1. Análisis comparativo entre México y Colombia, acción por omisión legislativa}

\begin{tabular}{|c|c|c|}
\hline Descripción & México & Colombia \\
\hline Plazo razonable & $\begin{array}{l}\text { Un elemento importante para } \\
\text { determinar si hay o no omisión } \\
\text { legislativa o reglamentaria es el } \\
\text { tiempo transcurrido entre la vi- } \\
\text { gencia de norma constitucional } \\
\text { que requiere para su desarrollo de } \\
\text { la ley o reglamento o, en su caso, } \\
\text { el vencimiento del plazo otorga- } \\
\text { do por el constituyente. }\end{array}$ & $\begin{array}{l}\text { Los fines esenciales del Estado } \\
\text { imponen al órgano legislativo } \\
\text { el deber de llevar a cabo, en un } \\
\text { plazo razonable, las reformas y } \\
\text { desarrollos legales necesarios para } \\
\text { garantizar la efectividad de las de- } \\
\text { cisiones del constituyente. }\end{array}$ \\
\hline \multirow{3}{*}{ Omisión legislativa } & $\begin{array}{l}\text { Chiapas: Se presenta cuando } \\
\text { el Congreso no resuelva alguna } \\
\text { iniciativa de ley o decreto den- } \\
\text { tro de los términos que esta- } \\
\text { blezca la legislación respectiva y } \\
\text { que dicha omisión afecte el de- } \\
\text { bido cumplimiento de la Cons- } \\
\text { titución Política del Estado de } \\
\text { Chiapas. }\end{array}$ & \multirow{3}{*}{$\begin{array}{l}\text { Se presenta cuando no produce } \\
\text { ningún precepto encaminado a } \\
\text { ejecutar el deber concreto que } \\
\text { le ha impuesto la Constitución; } \\
\text { cuando en cumplimiento del } \\
\text { deber impuesto por la Constitu- } \\
\text { ción, favorece a ciertos grupos, } \\
\text { perjudicando a otros; cuando en } \\
\text { desarrollo de ese mismo deber, } \\
\text { el legislador, en forma expre- } \\
\text { sa o tácita, excluye a un grupo } \\
\text { de ciudadanos de los beneficios } \\
\text { que otorga al resto; cuando el } \\
\text { legislador, al regular o construir } \\
\text { una institución, omite una con- } \\
\text { dición o un ingrediente que, de } \\
\text { acuerdo con la Constitución, se- } \\
\text { ría exigencia esencial para armo- } \\
\text { nizar con ella. }\end{array}$} \\
\hline & $\begin{array}{l}\text { Veracruz: Proceden cuando se } \\
\text { considere que el Congreso no } \\
\text { ha aprobado alguna ley o decre- } \\
\text { to y que dicha omisión afecte el } \\
\text { debido cumplimiento de esta } \\
\text { Constitución, que interponga: } \\
\text { a) El Gobernador del Estado, o } \\
\text { b) Cuando menos la } 3 \text { a parte de } \\
\text { los ayuntamientos. }\end{array}$ & \\
\hline & $\begin{array}{l}\text { Tlaxcala: Por la falta de expe- } \\
\text { dición de las normas jurídicas } \\
\text { de carácter general, a que estén } \\
\text { obligados en términos de las } \\
\text { Constituciones Políticas, de los } \\
\text { Estados Unidos Mexicanos, del } \\
\text { Estado y de las leyes. }\end{array}$ & \\
\hline
\end{tabular}




\begin{tabular}{|c|c|c|}
\hline Descripción & México & Colombia \\
\hline \multirow{3}{*}{$\begin{array}{l}\text { Medios de control } \\
\text { constitucional }\end{array}$} & $\begin{array}{l}\text { Acción por omisión legislativa. } \\
\text { Chiapas: Garantizar que el Poder } \\
\text { Legislativo como ente público del } \\
\text { Estado cumpla con su deber de } \\
\text { dotar a la comunidad de la cual } \\
\text { emana las leyes y disposiciones } \\
\text { legales que permitan la armónica } \\
\text { convivencia de los miembros de } \\
\text { ésta. }\end{array}$ & \multirow{3}{*}{$\begin{array}{c}\text { Acción pública de inconstitu- } \\
\text { cionalidad, el competente es la } \\
\text { Corte Constitucional en omisión } \\
\text { legislativa relativa. } \\
\text { En omisión legislativa absoluta } \\
\text { la Corte Constitucional no es } \\
\text { competente para conocer, de- } \\
\text { bido a que no existe norma por } \\
\text { demandar. }\end{array}$} \\
\hline & $\begin{array}{l}\text { Veracruz: El Estado de Veracruz } \\
\text { modificó su Constitución Polí- } \\
\text { tica en el } 2000 \text {, con la cual in- } \\
\text { cluyó como medios de control } \\
\text { constitucional a las controversias } \\
\text { constitucionales, a las acciones } \\
\text { de inconstitucionalidad y a las } \\
\text { acciones por omisión legislativa. }\end{array}$ & \\
\hline & $\begin{array}{l}\text { Tlaxcala: Otorgó competencia } \\
\text { al Pleno del Tribunal Superior } \\
\text { de Justicia, para que prevea las } \\
\text { acciones por omisión legislativa } \\
\text { contra el Congreso, el goberna- } \\
\text { dor y los ayuntamientos o conse- } \\
\text { jos municipales. }\end{array}$ & \\
\hline $\begin{array}{l}\text { Mecanismos para } \\
\text { subsanar la omisión } \\
\text { legislativa }\end{array}$ & Juicio de amparo. & $\begin{array}{l}\text { Sentencia integradora, sentencia } \\
\text { interpretativa o condicionada, } \\
\text { sentencia modulativa y exhorto } \\
\text { constitucional. }\end{array}$ \\
\hline
\end{tabular}

Fuente: Elaboración propia a partir de la investigación realizada.

\section{Colombia}

La clasificación más clásica es la planteada por el magistrado del Tribunal Constitucional alemán W. Wessel, la cual ha sido objeto de estudio por demás constitucionalistas y tratadistas. Para Wessel, la omisión legislativa absoluta: es aquella que presenta una ausencia total de la norma que debería regular una determinada situación jurídica fijada constitucionalmente. Mientras que en la omisión legislativa relativa, el legislador, al propulsar la norma para "obedecer" el mandato "constitucional", favorece a ciertos grupos y olvida a otros o acuerda ventajas a 
unos que no son dispensadas a otros, generando tentativamente las hipótesis a ser refundadas siempre en la siguiente fórmula: habrá omisión relativa toda vez que en el cumplimiento del mandato constitucional el órgano legislativo encargado de efectivizarlo quiebre en forma no intencional, pero produciendo un resultado discriminatorio y/o arbitrario el principio de igualdad. ${ }^{80}$ Así mismo, explica la procedibilidad de una demanda de constitucionalidad en ambas omisiones; por un lado, en la absoluta se niega toda posibilidad de instaurar dicha demanda; en cambio, en la relativa sí sería fiscalizable, en tanto que implica la vulneración inmediata por el legislador de un derecho fundamental. ${ }^{81}$

Otra clasificación que se encuentra es la omisión formal y material, la formal es aquella que supone que el legislador ha adoptado una posición total o parcialmente inactiva respecto del encargo que requiere ser desarrollado. La omisión material consiste en la inactividad que vulnera, específicamente, el principio de igualdad, debido a que el órgano legisferante olvida igualar la norma a todos los grupos que prevé. ${ }^{82}$

En contraste con estas clasificaciones, Néstor Pedro Sagüés las clasifica en dos formas distintas: la inconstitucionalidad por omisión por mora y la inconstitucionalidad por negación, haciendo referencia a la misma omisión relativa. La primera se divide en tres factores:

A. Inercia en adoptar una decisión concreta, como, por ejemplo, abstenerse de poner en libertad a alguien cuya detención ya no tiene ningún objeto al haber concluido legalmente.

B. Mora en la ejecución, que se produce cuando habiendo una decisión tomada, ésta no se cumple. Un ejemplo de esto lo tenemos en el caso de una pensión ya otorgada, pero que no se paga.

C. Tardanza en la producción de normas generales, también conocida como inconstitucionalidad legislativa; el caso más frecuente de esta modalidad, según Sagüés, es el ocio en el que incurre el Legislativo al omitir reglamentar aquello que requiere de ulterior desarrollo normativo.

80 BAZAN (2017), p. 105.

81 WESSEL (1952), p. 164.

82 Fernández (1998), p. 60. 
En cuanto a la inconstitucionalidad por negación o inconstitucionalidad por omisión relativa, es aquélla en donde el órgano legislativo incurre en una exclusión arbitraria de ciertos beneficios en perjuicio de un grupo de personas. ${ }^{83}$

\section{México}

La Suprema Corte de Justicia de la Nación mediante jurisprudencia ${ }^{84}$ realizó una clasificación acerca de la inconstitucionalidad por omisión legislativa, donde estableció cuatro categorías atribuibles a las obligaciones constitucionales del legislador:

A. Omisiones absolutas en competencias de ejercicio obligatorio, cuando el órgano legislativo tiene la obligación o mandato de expedir una determinada ley y no lo ha hecho.

B. Omisiones relativas en competencias de ejercicio obligatorio, cuando el órgano legislativo emite una ley teniendo una obligación o mandato para hacerlo, pero la concreta de manera incompleta o deficiente.

C. Omisiones absolutas en competencias de ejercicio potestativo, en las que el órgano legislativo decide no actuar debido a que no hay ningún mandato $\mathrm{u}$ obligación que así se lo imponga.

D. Omisiones relativas en competencias de ejercicio potestativo, en las que el órgano legislativo decide hacer uso de su competencia potestativa para legislar, pero al emitir la ley lo hace de manera incompleta o deficiente.

Por otro lado, César Astudillo la clasifica en omisión evidente y omisión oculta. La primera se refiere a la ausencia de una disposición frente a un mandato de la Constitución. La segunda se actualiza cuando lo que existe es la carencia de una norma que lesiona los contenidos constitucionales y que no es posible identificar a "simple vista", sino sólo a través de la intervención de un juez. ${ }^{85}$

Por último, dentro de este artículo, se encuentra la distinción por incidencia, que se presenta cuando la omisión legislativa afecta derechos fundamentales y cuando no los afecta. ${ }^{86}$

\footnotetext{
83 SAGUUÉs, p. 606.

84 Sentencia Corte Suprema de Justicia de la Nación, P./J. 11,2006 No 175872, febrero de 2006.

85 Astudillo (2007), p. 316.

86 Distinción central y principal en el estudio del texto desarrollado.
} 
Desde esta perspectiva, no existe unificación dentro del territorio mexicano acerca de cómo concretamente está establecido su uso, protección y alcances, es por esto que se desarrollará más adelante un acápite sobre la regulación que a nivel local se ha ido implementando como medio de control.

Por otra parte, en Colombia, jurisprudencialmente se han desarrollado dos clases de omisiones: la omisión absoluta y la omisión relativa; la primera se constituye cuando hay una falta total de una disposición de desarrollo legislativo de un determinado precepto constitucional; mientras que, en la segunda, el legislador ha expedido la ley, pero en ella solamente ha regulado algunas relaciones dejando por fuera otros supuestos análogos, con clara violación del principio de igualdad. ${ }^{87}$

En concepto de la Corte Constitucional, la omisión legislativa relativa se presenta cuando el legislador incumple una obligación derivada de la Constitución, que le impone adoptar determinada norma legal; y la omisión legislativa absoluta se presenta en caso de falta absoluta de regulación legal, cuando no pesa sobre el legislador el deber constitucional de proferir una determinada norma. ${ }^{88}$

Se puede entender que la omisión legislativa relativa se puede dar como una situación discriminatoria y, por lo tanto, una vulneración al derecho a la igualdad; sin embargo, la Corte Constitucional estableció que no es la única circunstancia en que ésta se puede constituir, siendo posible observar situaciones en las que el precepto ignora algún otro tipo de elemento normativo, que conforme a la disposición superior debe considerarse imperativo. Dentro de esas exigencias constitucionales pueden mencionarse la de considerar determinados objetivos al momento de regular una materia, la de incluir ciertas etapas esenciales en la regulación de un procedimiento, la de brindar instancias de participación a algunos sujetos específicos previamente a la decisión sobre temas que pueden afectarlos, y otras semejantes. ${ }^{89}$

\section{A MANERA DE CONCLUSIONES}

En México, en una primera etapa, la acción por omisión legislativa ha sido desarrollada sólo en algunas entidades federativas, no así a nivel nacional; sin embargo, la creación de este medio de control constitucional en el país no es ho-

87 Corte Constitucional, Sentencia C-543/1996, 16 de octubre de 1996.

88 Corte Constitucional, Sentencia C-173/2010, 10 de marzo de 2010.

89 Corte Constitucional, Sentencia C-314/2009, 5 de mayo de 2009. 
mogénea, cada Estado la ha implantado con sus peculiaridades ${ }^{90}$ y se encuentra destinada para los órganos públicos, quienes son a los que se les ha otorgado la legitimación para promoverla.

Una segunda etapa, que se inicia con la reforma a la CPEUM en materia de derechos humanos de 2011, y con la expedición de la Ley de Amparo de 2013, permite legitimar a los particulares a promover el juicio de amparo cuando a la autoridad responsable se le demande por omitir las disposiciones necesarias para dar cumplimiento a los mandatos de la CPEUM.

En la acción por omisión legislativa, en el caso del Estado de Chiapas, se cuestiona respecto al alcance de la resolución posible del Tribunal Constitucional que determine, cuando declare que ha habido una inconstitucionalidad por omisión del legislador y no cumpla con el fallo en tiempo se faculta, en rebeldía del órgano condenado, al Tribunal Constitucional para legislar de manera provisional las normas ausentes, sujetas a la condición resolutiva hasta que el legislador emita éstas.

Los críticos de este sistema señalan que es contrario a la teoría clásica la división de poderes, ya que vulnera a la propia CPEUM (a. 49) al establecer la prohibición de "No podrán reunirse dos o más de estos poderes en una sola persona o corporación”; sin embargo, es un argumento que se puede aplicar también cuando el Poder Judicial anula una ley (controversias constitucionales y acciones de inconstitucionalidad) o su aplicación a determinadas personas (juicio de amparo).

En la omisión legislativa para Chiapas encontramos un tribunal que puede actuar como legislador positivo, mientras que en los demás medios de control constitucional como en el legislador negativo.

La acción por omisión legislativa hasta ahora es un mecanismo estéril, porque si bien está legislado en las Constituciones locales no ha sido utilizado, debido al bajo nivel de democracia de los actores políticos, sometidos por regla al gobernador de la entidad, quien decide habitualmente todo y sus actos políticamente son incuestionables por los demás entes de poder.

Este déficit se engrandece ante la ahora exigencia del ejercicio del control difuso de constitucionalidad y convencionalidad de todo juez del país, aunado a la procedencia del juicio de amparo para combatir la acción por omisión legislativa o reglamentaria, que hunde más la nula eficacia de la justicia local mexicana.

Además de la procedencia del juicio de amparo como medio de control de los derechos humanos vulnerados por una omisión legislativa, tanto absoluta como relativa.

90 Como se demostró al desarrollar la diversidad de mecanismos que se presenta en las entidades mexicanas respecto de la aplicación de los medios de control en las omisiones legislativas y reglamentarias. 
Por otra parte, se insiste en la necesidad, por un lado, de unificar dentro de todo el territorio mexicano a la acción por omisión legislativa o reglamentaria en las entidades federativas, y su inclusión como medio de control constitucional de carácter federal, por ser un medio específico, diferente a las controversias constitucionales y a las acciones de inconstitucionalidad.

En lo que respecta a Colombia, es pertinente que se codifiquen dentro de un Código o una ley las omisiones legislativas y allí se contemplen las sanciones que se deben imponer al legislador, las cuales no se encuentran aún reguladas, ni los requisitos que debe contener los medios de control para impugnar dichas omisiones, dado que dentro del ordenamiento jurídico colombiano se torna como si fuera una demanda de inconstitucionalidad, que es un medio de control donde analiza el texto de la norma, para determinar si es contrario o no a la Constitución; en cambio, en la omisión, ahí se presenta la dificultad; si bien vimos que al omitirse una regulación o texto normativo se vulnera la Constitución, no es la finalidad de la acción de inconstitucionalidad, porque hay ausencia de texto para el estudio sobre la constitucionalidad de éste. Dejando una paradoja, dentro de la cual aún quedan vacíos, que se pueden interpretar como una omisión legislativa relativa dentro de la misma omisión legislativa.

\section{BiBLIOGRAFÍA CITADA}

\section{DOCTRINA}

Arteaga Nava, Elisur, (2003): Tratado de derecho constitucional, v. 1, (Oxford University Press, México).

Astudillo, César. (2007): La inconstitucionalidad por omisión legislativa en México.

(Instituto de Investigaciones Jurídicas, México).

BÁz SILVA, Carlos, (2002): La omisión legislativa y su inconstitucionalidad en México. (Revista Jurídica Nueva Serie, México).

BAZÁN, Víctor, (2014) Control de las omisiones inconstitucionales e inconvencionales. Recorrido por el derecho y la jurisprudencia americano y europeos. (Bogotá, Editorial Konrad Adenauer Stiftung). [Disponible en www.kas.de/wf/doc/ kas_40437-1522-4-30.pdf?150210170222].

BAZÁ, Víctor, (2017): "Respuestas normativas y jurisdiccionales frente a las omisiones inconstitucionales: una visión de derecho comparado". En CARBONELL, 
Miguel (coord.), En busca de las normas ausentes. Ensayos sobre la inconstitucionalidad por omisión, $2^{\text {a }}$ ed., Instituto de Investigaciones Jurídicas, UNAM. Biblioteca Jurídica Virtual del Instituto de Investigaciones Jurídicas de la UNAM: Procedencia del juicio de amparo para impugnar una reforma [fecha de consulta: 26 de junio de 2017]. [Disponible en https://archivos.juridicas. unam.mx/www/bjv/libros/7/3084/4.pdf].

Bulnes Aldunate, Luz (2006): La inconstitucionalidad por omisión. Centro de Estudios Constitucionales de Chile, vol. 4, (Estudios Constitucionales).

Cabanellas, Guillermo: Diccionario de derecho usual, 4a. ed., t. III. (Editorial Bibliográfica Omeba, Buenos Aires).

Castro PatiŇo, Iván, (s.f.): "Clasificación de las normas constitucionales. [Disponible” en http://www.revistajuridicaonline.com/wp-content/ uploads/2004/01/17_Clasificacion_Normas_Constitucionales.pdf].

Celemín Caicedo, Andrea, (2017): "El exhorto al legislador: Análisis en la jurisprudencia de la Corte Constitucional colombiana”. Revista Derecho Público. No 36.

CRuz Razo, Juan Carlos, (2017): Comisiones legislativas y juicio de amparo, (México).

Cubides Cárdenas, Jaime, Barreto Cifuentes, Paula Andrea, (2017): "Positivización del ordenamiento convencional interamericano en Colombia". En Velandia, Eduardo (Dir. Científico), Derecho Procesal Constitucional: Codifcación Procesal Constitucional. Bogotá, Colombia: Ediciones Nueva Jurídica.

Cubides Cardenas, Jaime, Castro Buitrago, Carlos Eduardo y Barreto CiFuentes, Paula Andrea, (2017): "El plazo razonable a la luz de los estándares de la jurisprudencia de la Corte Interamericana de Derechos Humanos". En Cubides, Jaime (Ed.), Desafios contemporáneos de la protección de los derechos humanos en el Sistema Interamericano. Bogotá, Colombia: Universidad Católica de Colombia.

Cubides Cárdenas, Jaime, Chacón Triana, Nathalia, y Martínez Lazcano, Alfonso Jaime, (2015): El control de convencionalidad (CCV): retos y pugnas. Una explicación taxonómica, (Academia \& Derecho).

Cubides Cardenas, Jaime, Gonzáles Garcete, Juan Marcelino y Santofimio Díaz, María Paula, (2015): La inconstitucionalidad por la omisión legislativa: a escena la omisión legislativa convencional, (Iustitia, Colombia).

Cubides Cárdenas, Jaime, Grandas Ferrand, Angélica y González Garcete, Juan Marcelino, (2017): "Constitucionalismo multinivel (CM): El nuevo 
paradigma en la protección de los derechos fundamentales". En Agudelo, Óscar (Ed.), Perspectivas del constitucionalismo. Bogotá, Colombia: Universidad Católica de Colombia.

Diccionario Jurídico Mexicano. (1996): Instituto de Investigaciones Jurídicas, 9a. Edición (Editorial Porrúa, México).

Fernández Rodríguez, José Julio. (2003): Justicia Local Constitucional. La omisión legislativa en la Constitución del Estado de Veracruz-Llave en el marco de la teoria general de dicho instituto, (México).

FERnÁndez Rodríguez, José Julio. (1998): La inconstitucionalidad por omisión: teoría general; derecho comparado; el caso español. (Civitas, Madrid).

Ferrajol, Luigi (2001): Derechos y garantías. La ley del más débil, (Madrid. Trotta). Ferrer Mac-Gregor, Eduardo, (2003): Derecho procesal constitucional, (Editorial Porrúa, México).

Fundación Universitaria de Derecho, Administración y Política, (2003): Justicia Local Constitucional. y su Defensa. Elementos para una Teoria del Control de la Constitucionalidad, Ed. FUNDAp, (México).

Gomes Canotilho, José Joaquim, (1993): Direito constitucional. (Coimbra, Almedina).

Gonzales Noriega, Olga Cecilia, (2014): La Corte Constitucional como agente del campo juridico colombiano: la omisión legislativa de principios constitucionales. González Oropeza, Manuel, (1993): Las controversias entre la Constitución y la politica, Cuadernos Constitucionales México-Centroamérica, Instituto de Investigaciones Jurídicas, (México).

Martínez Lazcano, Alfonso Jaime: Justicia constitucional en Chiapas, Biblioteca Jurídica Virtual, Instituto de Investigaciones Jurídicas-UNAM, (consultado: 12 de junio de 2015. Véase en: https://archivos.juridicas.unam.mx/www/ bjv/libros/7/3032/13.pdf).

Nuevos mecanismos de control constitucional en el Estado de Tabasco, Perfiles de las Ciencias Sociales, Año 4, Número Especial 1, 2017, pp. $32-57$ (Consultado 12 de mayo de 2017, http://revistas.ujat.mx/index.php/perfiles/article/ view/1774).

Olano García, Hernán Alejandro, (2004): Tipología de nuestras sentencias constitucionales.

Osorio, Manuel, (1992): Diccionario de ciencias juridicas, politicas y sociales, (Buenos Aires). 
Rangel Hernandez, Laura, (2008): La acción de inconstitucionalidad por omisión legislativa en la Constitución mexicana. Un avance en el acceso a la justicia constitucional.

SAGÜÉs, Néstor Pedro, (sin fecha): Instrumentos de la justicia constitucional frente a la inconstitucionalidad por omisión. (Centro Interdisciplinario de Derecho Procesal).

VillaVerde MenÉNDEZ, Ignacio, (1997): La inconstitucionalidad por omisión. Madrid, McGraw-Hill.

WeSSEL, W., (1952): Die Rechtsprechung des Bundesverfassungsgerichts zur Verfassun. Zapata Marín, Ángel Darién, (2014): Las omisiones legislativas y el juicio de amparo, un análisis desde la perspectiva de los derechos humanos a la luz del derecho de acceso a la justicia. (México).

\section{JURISPRUDENCIA CITADA}

Acción de inconstitucionalidad 27/2002, Semanario Judicial de la Federación y su Gaceta, marzo de 2003.

Acción de inconstitucionalidad 27/2002, promovida por el Partido de la Revolución Democrática, Semanario Judicial de la Federación y su Gaceta, novena época, t. XVII, marzo de 2003, p. 1047.

Corte Constitucional, Sentencia de acción de inconstitucionalidad C-543/1996, 16 de octubre de 1996.

Corte Constitucional, Sentencia de acción de inconstitucionalidad C-215/1999, 14 de abril de 1999.

Corte Constitucional, Sentencia de acción de inconstitucionalidad C-577/11, 26 de julio de 2011.

Corte Constitucional, Sentencia de acción de inconstitucionalidad C- 543/1996, 16 de octubre de 1996.

Corte Constitucional, Sentencia de acción de inconstitucionalidad C-188/1996. 8 de mayo de 1996.

Corte Constitucional, Sentencia de acción de inconstitucionalidad C-1004/2007, 22 de noviembre de 2007.

Corte Constitucional, Sentencia de acción de constitucionalidad C-173/2010, 10 de marzo de 2010.

Corte Constitucional, Sentencia de acción de inconstitucionalidad C-1153/2005, 11 de noviembre de 2005. 
Corte Constitucional, sentencia de acción de inconstitucionalidad C-041/2002, 30 de enero de 2002.

Corte Constitucional, Sentencia de acción de inconstitucionalidad C-038/2006, 1 de febrero de 2006.

Corte Constitucional, Sentencia de acción de inconstitucionalidad C-314/2009. 5 de mayo de 2009.

Corte Constitucional, Sentencia de acción de inconstitucionalidad C-415/2012. 6 de junio de 2012.

Corte IDH. Caso Genie Lacayo Vs. Nicaragua. Fondo, Reparaciones y Costas. Sentencia del 29 de enero de 1997. Serie C No 30, Párrafo 77.

Corte IDH. Caso La Cantuta Vs. Perí. Fondo, Reparaciones y Costas. Sentencia de 29 de noviembre de 2006. Serie C No 162, Párrafo 149.

Corte Suprema de Justicia de la Nación, 1 de febrero de 2008, (acción de inconstitucionalidad) en: Semanario Judicial de la Federación y su Gaceta, Tomo 27 (2008), novena época, p. 1336.

Corte Suprema de Justicia de la Nación, febrero de 2006, en: Semanario Judicial de la Federación y su Gaceta, Tomo 23 (2006), novena época, p. 1527.

Semanario Judicial de la Federación, t. X, agosto de 1999, p. 18.

Tesis: I.18o.A.10K, Semanario Judicial de la Federación y su Gaceta, Libro 35, octubre de 2017, Tomo IV, (10a.), p. 2996.

Tesis: I.18o.A.11 K (10a.), Semanario Judicial de la Federación y su Gaceta, Libro 35, octubre de 2017, Tomo IV, p. 2995.

Tesis: I.40.A.21 K (10a.), Gaceta del Semanario Judicial de la Federación, Instancia: Tribunales Colegiados de Circuito, Libro 1, diciembre de 2013, Tomo II, p. 1200.

Tesis: I.4o.A.22 K (10a.), Gaceta del Semanario Judicial de la Federación, Libro 1, diciembre de 2013, Tomo II, p. 1199.

Tesis: P. LXXX/99, Semanario Judicial de la Federación y su Gaceta, Tomo X, noviembre de 1999 , p. 40. 